DOE/RL-95-78

Revision 0

\title{
PUREX Facility Preclosure Work Plan
}

United States
Department of Energy
Richland, Washington

Approved for Public Release 
TRADEMARK DISCLAIMER

Reference herein to any specific commercial product, process, or service by trade name, trademark, manufacturer, or otherwise, does not necessarily constitute or imply its endorsement, tecommendation, or favoring by the United States Government or any agency thereof or its contractors or subcontractors.

This report has been reproduced from the best available copy. Available in paper copy and microfiche.

Available to the U.S. Department of Energy and its contractors from

Office of Scientific and Technical Inforrnation P.O. Box 62

Oak Ridge, TN 37831

(615) $576-8401$

Available to the public from the U.S. Department of Cornmerce National Technical Information Service

5285 Port Royal Road

Springfield, VA 22161

(703) $487-4650$

Printed in tho United States of Americe

DISCLM-5.CHP (8-91) 
옹 
DOE/RL-95-78, Rev. 0

06/96

\author{
PUREX FACILITY \\ PRECLOSURE WORK PLAN
}

\section{FOREWORD}

The Hanford Facility is owned by the U.S. Government and operated by the U.S. Department of Energy, Richland Operations Office. Dangerous waste and mixed waste (containing both dangerous and radioactive components) are produced and managed on the Hanford Facility. Waste components are regulated in accordance with the Resource Conservation and Recovery Act of 1976 and Hazardous and Solid Waste Amendments of 1990, and/or the State of Washington Hazardous Waste Management Act of 1976 (as administered through the Washington State Department of Ecology's Dangerous Waste Regulations, Washington Administrative Code 173-303); or the Atomic Energy Act of 1954.

For the purposes of the Resource Conservation and Recovery Act of 1976, the Hanford Facility is considered to be a single facility. A single dangerous waste permit identification number issued to the Hanford Facility by the U.S. Environmental Protection Agency and the Washington State Department of Ecology is Environmental Protection Agency/State Identification Number WA7890008967. This identification number encompasses a number of treatment, storage, and/or disposal units within the Hanford Facility. One of these treatment, storage, and/or disposal units is the PUREX Facility.

The PUREX Facility is currently undergoing a phased closure. Thus, the PUREX Facility Preclosure Work Plan submittal differs from closure plans previously submitted by the U.S. Department of Energy, Richland Operations Office to the Washington State Department of Ecology, in that the closure process occurs in three distinct phases as part of the decommissioning process [i.e., transition, surveillance and maintenance, and disposition (Hanford Federal Facility Agreement and Consent Order, Section 8.0)]. Final closure will occur during the disposition phase. The phased decommissioning process is implemented because development of a complete closure plan during the transition phase is impractical and future land use determinations have not been identified.

The PUREX Facility Preclosure Work Plan is prepared in accordance with the PUREX Facility transition phase as outlined in Section 8.0 of the Hanford Federal Facility Agreement and Consent Order (Ecology et al. 1996). The objective of the transition phase is to place the PUREX facility in a safe configuration with respect to human health and the environment. Following the transition phase activities, the PUREX Facility will begin the surveillance and maintenance phase of 10 or more years until disposition phase activities commence. The closure plan for the PUREX Facility will be prepared during the disposition phase.

For purposes of this documentation, the PUREX Facility does not include the PUREX Storage Tunnels. The PUREX Storage Tunnels are an operating storage unit (DOE/RL-90-24). 
DOE/RL-95-78, Rev. 0 06/96

This page intentionally left blank. 
$\frac{8}{3}$ 
8 METRIC CONVERSION CHART

9

10

11

143.0 PROCESS INFORMATION

1.0 INTRODUCTION

2.0 FACILITY DESCRIPTION

4.0 WASTE CHARACTERISTICS

5.0 GROUNDWATER

6.0 TRANSITION PHASE STRATEGY

7.0 TRANSITION PHASE ACTIVITIES

8.0 POSTCLOSURE PLAN

9.0 REFERENCES

27 
D0E/RL-95-78, Rev. 0

$06 / 96$

This page intentionaliy left blank. 
\{ 
8 
ASF

CFR

$\mathrm{CO}^{\mathrm{C}}$

DOE

DQO

DST

EPA

NO

NPH

S\&M

$T$

TK

TSD

UNH

WAC

\section{GLOSSARY}

\section{ACRONYMS AND ABBREVIATIONS}

AFAN

CERCLA

DOE-RL

\section{Ecology}

$\mathrm{NaNO}_{2}$

$\mathrm{NaOH}$

NEPA

NZAW

PUREX

RCRA

Tri-Party Agreement

oxides of carbon

double-shel1 tank

sodium nitrite

sodium hydroxide

oxides of nitrogen

tank ammonium fluoride-ammonium nitrate ammonia scrubber feed

Comprehensive Environmental Response, Compensation, and Liability Act of 1980

Code of Federal Regulations

cladding removal waste

U.S. Department of Energy

U.S. Department of Energy, Richland Operations Office data quality objectives

Washington State Department of Ecology

U.S. Environmental Protection Agency

National Environmental Policy Act of 1969

normal paraffin hydrocarbon

neutralized zirflex acid waste

plutonium-uranium extraction

Resource Conservation and Recovery Act of 1976

surveillance and maintenance

tower (generic term used for column, scrubber, etc.)

Hanford Federa] Facility Agreement and Consent Order treatment, storage, and/or disposal

uranyl nitrate hexahydrate

Washington Administrative Code 
TERMS

Definitions are based on use throughout this document.

Crib--A porous underground structure for disposal of liquid waste.

Dunnage--The nonprocess structure component of process equipment assembly used to support, maintain spacial configuration, and facilitate remote handling.

Waste fission products--Byproducts of nuclear fission, other than plutonium, uranium, and neptunium that were produced by irradiation and extracted through the PUREX process.

Jumper--A prefabricated, remotely installed, piping assembly used to make intra-cell transfers between process equipment. The piping assembly could contain connectors, valves, instrumentation, and counterweights.

M--Molar, or moles, of solute per 1 iter of solution.

Metathesis--A process of reacting potassium hydroxide with residual fluorides remaining on the fuel elements after the fuel elements have been decladded with an ammonium fluoride-ammonium nitrate solution. This reaction complexes the fluoride so the fluoride can be removed from the dissolvers to minimize dissolver corrosion during the fuel dissolution process.

Mixed waste--A dangerous, extremely hazardous, or acutely hazardous waste that contains both a nonradioactive hazardous component and source, special

nuclear, or by-product material subject to the Atomic Energy Act of 1954 .

$N$ Reactor--A graphite-moderated, water-cooled reactor that produced irradiated fuel for processing at the PUREX P1ant. The steam byproduct was used to generate electricity.

pH--The negative log of the hydrogen ion concentration in a solution.

PUREX--plutonium-uranium extraction.

PUREX Facility--A1] buildings and structures that lie within, or adjacent, to the double fenced area. For purposes of this documentation, the PUREX Storage Tunnels (DOE/RL-90-24) are excluded.

PUREX Plant--The PUREX processing building, 202-A Building.

Zirflex--A buffered acidic ammonium fluoride process for the dissolution of zirconium alloy cladding from irradiated reactor fuel assemblies. 
Into metric units

Out of metric units

\begin{tabular}{|c|c|c|c|c|c|}
\hline If you know & $\begin{array}{l}\text { Multiply } \\
\text { by }\end{array}$ & To get & If you know & $\begin{array}{c}\text { Multiply } \\
\text { by }\end{array}$ & To get \\
\hline \multicolumn{3}{|c|}{ Length } & \multicolumn{3}{|c|}{ Length } \\
\hline inches & 25.40 & millimeters & millimeters & 0.0393 & inches \\
\hline inches & 2.54 & centimeters & cent imeters & 0.393 & inches \\
\hline feet & 0.3048 & meters & meters & 3.2808 & feet \\
\hline yards & 0.914 & meters & meters & 1.09 & yards \\
\hline miles & 1.609 & kilometers & kilometers & 0.62 & miles \\
\hline \multicolumn{3}{|c|}{ Area } & \multicolumn{3}{|c|}{ Area } \\
\hline $\begin{array}{l}\text { square } \\
\text { inches }\end{array}$ & 6.4516 & $\begin{array}{l}\text { square } \\
\text { centimeters }\end{array}$ & $\begin{array}{l}\text { square } \\
\text { centimeters }\end{array}$ & 0.155 & $\begin{array}{l}\text { square } \\
\text { inches }\end{array}$ \\
\hline square feet & 0.092 & $\begin{array}{l}\text { square } \\
\text { meters }\end{array}$ & $\begin{array}{l}\text { Square } \\
\text { meters }\end{array}$ & 10.7639 & $\begin{array}{l}\text { square } \\
\text { feet }\end{array}$ \\
\hline $\begin{array}{l}\text { square } \\
\text { yards }\end{array}$ & 0.836 & $\begin{array}{l}\text { square } \\
\text { meters }\end{array}$ & $\begin{array}{l}\text { square } \\
\text { meters }\end{array}$ & 1.20 & $\begin{array}{l}\text { square } \\
\text { yards }\end{array}$ \\
\hline $\begin{array}{l}\text { square } \\
\text { miles }\end{array}$ & 2.59 & $\begin{array}{l}\text { square } \\
\text { kilometers }\end{array}$ & $\begin{array}{l}\text { square } \\
\text { kilometers }\end{array}$ & 0.39 & $\begin{array}{l}\text { square } \\
\text { miles }\end{array}$ \\
\hline acres & 0.404 & hectares & hectares & 2.471 & acres \\
\hline \multicolumn{3}{|c|}{ Mass (weight) } & \multicolumn{3}{|c|}{ Mass (weight) } \\
\hline ounces & 28.35 & grams & grams & 0.0352 & ounces \\
\hline pounds & 0.453 & kilograms & kilograms & 2.2046 & pounds \\
\hline short ton & 0.907 & metric ton & metric ton & 1.10 & short ton \\
\hline \multicolumn{3}{|c|}{ Volume } & \multicolumn{3}{|c|}{ Volume } \\
\hline $\begin{array}{l}\text { fluid } \\
\text { ounces }\end{array}$ & 29.57 & millititers & milliliters & 0.03 & $\begin{array}{l}\text { fluid } \\
\text { ounces }\end{array}$ \\
\hline guarts & 0.95 & Titers & Titers & 1.057 & quarts \\
\hline galions & 3.79 & Titers & Titers & 0.26 & gallons \\
\hline cubic feet & 0.03 & $\begin{array}{l}\text { cubic } \\
\text { meters }\end{array}$ & $\begin{array}{l}\text { cubic } \\
\text { meters }\end{array}$ & 35.3147 & cubic feet \\
\hline cubic yards & 0.76456 & $\begin{array}{l}\text { cubic } \\
\text { meters }\end{array}$ & $\begin{array}{l}\text { cubic } \\
\text { meters }\end{array}$ & 1.308 & $\begin{array}{l}\text { cubic } \\
\text { yards }\end{array}$ \\
\hline \multicolumn{3}{|c|}{ Temperature } & \multicolumn{3}{|c|}{ Temperature } \\
\hline Fahrenheit & $\begin{array}{l}\text { subtract } \\
32 \text { then } \\
\text { multiply } \\
\text { by } 5 / 9 \text { ths }\end{array}$ & Celsius & Ce1sius & $\begin{array}{l}\text { multiply } \\
\text { by } \\
9 / 5 \text { ths, } \\
\text { then add } \\
32\end{array}$ & Fahrenheit \\
\hline \multicolumn{3}{|c|}{ Force } & \multicolumn{3}{|c|}{ Force } \\
\hline $\begin{array}{l}\text { pounds per } \\
\text { square inch }\end{array}$ & 6.895 & kilopascals & kilopasca7s & $1.4504 \times$ & $\begin{array}{l}\text { pounds per } \\
\text { square } \\
\text { inch }\end{array}$ \\
\hline
\end{tabular}

Source: Engineering Unit Conversions, M. R. Lindeburg, PE., Second Ed., 1990, Professional Publications, Inc., Belmont, California. 


\section{DOE/RL-95-78, Rev. 0 \\ 06/96}

This page intentionally left blank. 


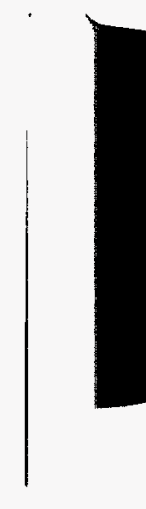




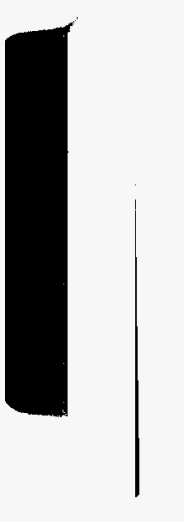

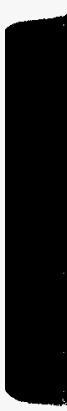

更

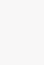

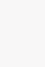

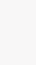

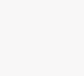

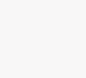

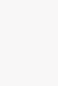

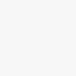

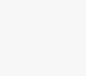

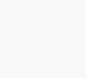

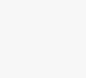

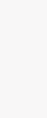

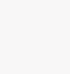

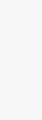

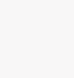

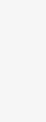

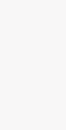
(2) (2) (2)
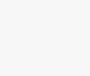

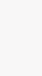
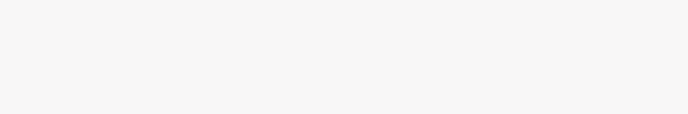
DOE/RL-95-78, Rev. 0

06/96

1

2

3

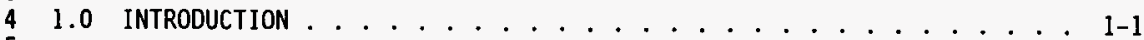
5 
DOE/RL-95-78, Rev. 0

06/96

This page intentionally left blank. 


\subsection{INTRODUCTION}

This preclosure work plan presents a description of the PUREX Facility, the history of the waste managed, and addresses transition phase activities that position the PUREX Facility into a safe and environmentally secure configuration. For purposes of this documentation, the PUREX Facility does not include the PUREX Storage Tunnels (DOE/RL-90/24).

The PUREX Facility Preclosure Work Plan is prepared in accordance with Section 8.0 of the Hanford Federal Facility Agreement and Consent Order (Tri-Party Agreement) (Ecology et a). 1996). The PUREX Facility Preclosure Work Plan submittal differs from closure plans previously submitted by the U.S. Department of Energy, Richland Operations Office (DOE-RL) to the Washington State Department of Ecology (Ecology), in that the closure process occurs in three distinct phases as part of the decommissioning process [i.e., transition, surveillance and maintenance (S\&M), and disposition (Ecology et a]. 1996)]. Final closure of the PUREX Facility will occur during the disposition phase. A PUREX Facility closure plan will be prepared during the disposition phase planning process, which follows an extended S\&M phase.

Planning documents supporting the transition phase activities include end point criteria (WHC 1995a) and a S\&M plan (WHC 1995b). On completion of the transition phase activities, the PUREX Facility will enter the S\&M phase. Tri-Party Agreement negotiations during S\&M and disposition phases will address closure activities.

The PUREX Facility was designed and constructed to provide supplemental fuel reprocessing capability to separate uranium, plutonium, and neptunium products from irradiated reactor fuel. The PUREX Facility operated from 1956 to 1972, when operations were placed in a standby mode. Operation resumed in 1983 after a backlog of irradiated fuel from $N$ Reactor was accumulated. In 1991, operations once again were placed in a standby mode. In December 1992, DOE-Headquarters notified the DOE-RL that the PUREX Facility would no longer operate and directed the DOE-RL to deactivate this facility.

Preclosure of the PUREX Facility vessel systems and removal of waste from the canyon deck will occur in conjunction with the overall decommissioning of the PUREX Facility. A vessel system is a treatment and/or storage vessel and its ancillary equipment. The transition phase activities place the PUREX Facility in a deactivated state where all regulated vessels are flushed until solutions do not designate as dangerous waste. The S\&M phase will maintain the PUREX Facility in a safe and environmentally secure configuration for 10 or more years for a planning horizon. The disposition phase will address final closure activities [for portions of the PUREX Facility identified in the Part A, Form 3, Permit Application (DOE/RL-88-21)] in accordance with Dangerous Waste Regulations, Washington Administrative Code (WAC) 173-303. If required, postclosure care requirements would be integrated with the post-remediation groundwater monitoring requirements established for the 200-P0-1 operable unit. 
1 This phased approach to closure allows for an expedient full deactivation 2 of the PUREX Facility in a manner that is safe and cost effective, while 3 minimizing the risk to human health and the environment.

The transition phase activities will place the PUREX Facility in a deactivated state. The transition phase consists of completion of end point criteria (WHC 1995b), flushing vessel systems until threshold levels are met, and transfer of the lead and cadmium waste from the canyon deck to PUREX Storage Tunnel Number 2. End point criteria are used to achieve a safe, stable, and environmentally secure facility suitable for a low cost S\&M

11 program. There are 10 treatment and/or storage vessel systems and 35 storage vessel systems addressed in this preclosure work plan [refer to Part $A$ 13 (DOE/RL-88-21)]. 
1 


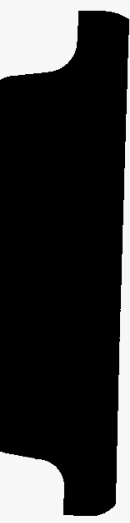




\section{CONTENTS}

2.0 FACILITY DESCRIPTION . . . . . . . . . . . . 2-1

2.1 PUREX FACILITY DESCRIPTION .............. . 2-1

2.2 PUREX FACILITY TREATMENT AND STORAGE AREAS . . . . . . . 2-2

2.2.1 Treatment and/or Storage Vessel Systems ...... 2-2

2.2.1.1 Tank E5 (cladding removal waste treatment system) ..................... 2-3

2.2.1.2 Tanks F15 and F16 (neutralized zirflex acid waste treatment system) ......... 2-3

2.2.1.3 Tank F18 (miscellaneous mixed waste treatment system) ................. 2-3

2.2.1.4 Tank G7 and Concentrator E-FII (headend waste treatment system) .......... 2-4

2.2.1.5 Tanks U3 and U4 (miscell aneous headend waste treatment system) ........... 2-4

2.2.1.6 Tanks $Q 21$ and $Q 22$ ( $Q$ Celi aqueous makeup tanks) ............. 2-5

2.2.2 PUREX Plant Containment Buijding . . . . . . $2-5$

2.3 SECURITY INFORMATION $\ldots \ldots \ldots \ldots \ldots$

\section{FIGURES}

2-1. 200 East Area . . . . . . . . . . . . . . . . . . . . F2-1

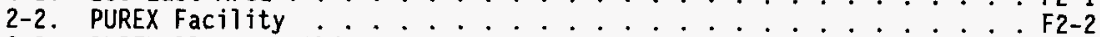

2-3. PUREX Plant (Building 202-A) . . . . . . . . . . . . . . F2-3

2-4. PUREX Plant Cross-Section (looking west) . . . . . . . . . . F2-4 
DOE/RL-95-78, Rev. 0

06/96

This page intentionally left blank. 


\subsection{FACILITY DESCRIPTION}

This chapter describes the PUREX Facility and provides information on hanford Facility security.

\subsection{PUREX FACILITY DESCRIPTION}

The PUREX Facility, Figures $2-1$ and $2-2$, is located in the southeast quadrant of the 200 East Area. The PUREX Facility includes all buildings and structures that 1 ie within the double fenced area, except the 241-A-151 diversion box and the 302-A catch tank, which are part of the Double-Shell Tank (DST) System (DOE/RL-90-39). The PUREX Facility also includes the following structures located outside of the double fenced area: the 241-A-201 pump pit and the 295-AD instrument/sample shack located outside the east section of the fenced area; the 216-A-42D diversion box and the 216-A-42 diversion basin located approximately 549 meters east of the fenced area, which are associated with the chemical sewer discharge from the PUREX Facility. For purposes of this documentation, the PUREX Storage Tunnels (DOE/RL-90-24) are excluded.

The 202-A Building (referred to as the PUREX Plant) is a canyon-type building where irradiated reactor fuel was processed to separate the plutonium, uranium, and neptunium from the highly radioactive waste fission products formed during fuel irradiation. Construction of the PUREX P] ant was completed in 1956. The PUREX P1ant is approximately 91 meters above groundwater and does not lie within a 100- or 500-year floodplain (DOE/RL-91-28). (Processing information is presented in Chapter 3.0.)

Cutaway and sectional views of the PUREX Plant are shown in Figures 2-3 and 2-4, respectively. The PUREX P1ant is a reinforced concrete structure 306 meters long, 36 meters wide (at its maximum), and 30 meters high with about 12 meters of this height below ground 7eve1. The PUREX Plant consists of three main structural components: (1) a thick-walled (for radiation shielding) concrete canyon containing remotely operated process equipment (in cells below ground level); (2) the pipe and operating, sample, and storage galleries; and (3) a steel-frame attached annex that includes offices, process control rooms, laboratories, and building services. Three cranes are located in a craneway above the canyon. The portion of the canyon below ground level is subdivided into a row of 12 process cells that are paralleled on the south side by an exhaust air tunnel and a hot (radioactive) pipe trench through which intercell radioactive solution transfers are made. The air tunnel exhausts the ventilation air from the cells to the main ventilation filters and the filtered air is discharged to the atmosphere via a 61-meter-tall stack.

The PUREX Plant canyon is 9.3 meters wide by 248 meters long. The upper canyon deck consists of removable concrete cover blocks that provide access to the process cells or the hot pipe trench. The cell cover blocks are 0.9-meter thick and the hot pipe trench cover blocks are 0.8-meter thick. The top of 
1 the cover blocks is at a 218 meter elevation, which is approximately

22.5 meters above ground level.

3

The craneway is 8 meters above the canyon deck and extends almost the full length of the canyon building. In the craneway are three, 36-metric ton, bridge-type cranes (two master cranes and one slave crane) used to handle cell cover blocks, remotely remove process equipment; and in the past, were used to charge irradiated reactor fuel into the dissolvers and replace process equipment. The crane cabs of the two master cranes are located behind a shielding parapet wall. The slave crane can be controlled remotely from the master west crane cab and has been used primarify to assist in removing large equipment items from the process cells.

The pipe and operating gallery, which is the uppermost of the three galleries that paralle?, but are isolated from, the canyon, contains the process instrument transmitter racks, electrical motor controls, steam and cooling-water supply lines, and the piping and associated valving for transferring nonradioactive process fluids used in the in-cell equipment. The sample gallery contains the remote samplers for obtaining radioactive, process-solution samples from the in-cell equipment. The storage gallery, which is the lowermost gallery, provides storage space for miscellaneous, nonradioactive spare parts and supplies.

A railroad spur enters the PUREX Facility (Figure 2-3) from the north and extends into the east end of the PUREX Plant where the spur enters a vertical door to an area designated as the railroad tunnel. Through this railroad tunnel, irradiated reactor fuel was received for processing. The railroad tunnel also provided building access for replacement equipment for the canyon processing area. Access from the railroad tunnel to the canyon processing area is through a horizontal door located in the ceiling of the railroad tunnel. The reinforced concrete floor, walls, and roof of the railroad tunnel that extend southward have been deleted from figure 2-3 to show a cask car and the extended railroad track.

\subsection{PUREX FACILITY TREATMENT AND STORAGE AREAS}

The activities addressed in this preclosure work plan involve the following specific vessel systems within the PUREX Facility. A description of the 'containment building' for the canyon deck and F Cell storage areas is provided in Section 2.2.2.

\subsubsection{Treatment and/or Storage Vesse1 Systems}

There are 10 treatment and/or storage vessel systems and 35 storage vessel systems [refer to Part A (DOE/RL-88-21)]. A vessel system is a treatment and/or storage vessel and its ancillary equipment.

The 35 storage vessel systems were used specifically to support transition phase activities. Because these vessels were used only for storage of dangerous solutions (mainiy flush solutions) until the solutions could be 
treated and transferred to the DST System, these vessels are not described in detail.

The following sections give a brief description of the six process systems, specifying the vessel and ancillary equipment.

2.2.1.1 Tank E5 (cladding removal waste treatment system). Tank E5 is a cylindrical, 19,873-1 iter capacity 304L stainiess steel tank located in E Cell. The tank shell is 2.8 meters in height, 3.1 meters in diameter, and constructed with 1.4-centimeter-thick top and bottom walls and 0.8-centimeterthick side walls. The top of the tank contains 22 nozzles of various size to accommodate anciliary equipment. Ancillary equipment associated with the tank consists of the following:

- Two jumpers (304L stainless steel) that lead from tank E5 to the hot pipe trench

- Hot pipe trench piping (Schedule 40 304L stainless steel) between the tank and the discharge piping

- Discharge piping (Schedule 40 304L stainless steel) that runs from the last jumper out (underground) to the $241-A-151$ diversion box, which is the interface point with the DST System.

The original tank, which was placed into service in 1956, was replaced in 1986 because corrosion of the dunnage and support frame around the tank caused a slight shift in the position of the tank. The current tank E5 has been in service since 1986 .

\subsubsection{Tanks F15 and F16 (neutralized zirflex acid waste treatment system).} Tanks F15 and F16 are cylindrical, 19,419- and 19,870-1iter, respectively, capacity 304L stainless steel tanks located in $\mathrm{F} \mathrm{Cell.} \mathrm{The} \mathrm{construction} \mathrm{is}$ the same as tank E5 discussed previously. The ancillary equipment associated with the tanks consists of the following:

- Two jumpers (304L stainless steel), one from tank F15 to F16, the other from tank F16 to the hot pipe trench

- Hot pipe trench piping (Schedule 40304 L staintess steel) between the tanks and the discharge piping

- Discharge piping (Schedule 40 304L stainless steel) from the hot pipe trench to the outside wall of the PUREX Plant and through encased underground piping to the DST System.

Tanks F15 and Fl6 originally were placed into service in 1965.

2.2.1.3 Tank F18 (miscellaneous mixed waste treatment system). Tank F18 is a cylindrica1, 19,798-liter capacity 304L stainless steel tank located in $F$ Ce]1. Tank F18 is the same type of construction as tanks E5, F15, and F16. The ancillary equipment consists of the following: 
- Jumper (304L stainless steel) from tank F18 to the hot pipe trench

- Hot pipe trench piping (Schedule 40 304L stainless stee1) between the tank and the discharge piping

- Discharge piping (Schedule $40304 L$ stainless steel) from the hot pipe trench to the 241-A-151 diversion box.

Tank F18 was placed in service in 1956.

2.2.1.4 Tank $\mathbf{G 7}$ and Concentrator E-F11 (headend waste treatment system). Tank G7 is an oval, 50,827-1iter capacity 304L stainless steel tank located in G Cell. Tank G7 is 5 meters long, 3.2 meters wide, 4 meters tall, and constructed with 0.9 -centimeter-thick side walls and 1.4-centimeter-thick top and bottom walls. The top of the tank contains 23 nozzles of various sizes to accommodate ancillary equipment.

The ammonia waste concentrator, hereafter referred to as E-F1l, [E identifies a heat exchanger (e.g., condenser, concentrator, or steam heater)], is located in F Cell. The E-F1l is constructed of 304L stainless steel; has a capacity of 9,804 liters; is 5.2 meters tall; and has a central draft tube, 76 centimeters in diameter, in the lower portion of the concentrator connected on opposite sides to two cylindrical reboilers, each 1.4 meters in diameter. The reboilers are connected to the draft tube by ducts at the top and bottom. A removable de-entrainment tower, 1.7 meters in diameter and 3.8 meters tali, is connected to the top of the draft tube with a bolted flange. Ancillary equipment for tank G7 and E-F1l includes the following:

- Catch tanks A3-4, B3-4, C3-4 (8,000 7iters each) and E3-2 (946 liters), each constructed of 304L stainless steel

- Accumulation tank F12 $(19,870$ liters), constructed of 304L stainless stee?, and piping from the catch tanks to tank F12

- Hot pipe trench piping (Schedule 40 304L stainless stee1) between vessels and discharge piping

- Various jumpers (304L stainless steel) that interconnect the vessels of the headend waste treatment system

- Discharge piping (Schedule $40304 \mathrm{~L}$ stainless stee1) from the hot pipe trench to the outside wall of the PUREX Plant and through encased underground piping to the DST System.

Tank G7 originally was placed into service in 1956. The E-F1l was placed into service in 1962 and was removed and replaced in 1970.

2.2.1.5 Tanks $U 3$ and $U 4$ (miscellaneous headend waste treatment system). Tanks U3 and U4, 31,124- and 31,184-1iter capacity, respectively, are 3.1 meters in diameter and 6.1 meters high. Both tanks are constructed of $304 \mathrm{~L}$ stainiess steel with a minimum thickness of 0.8 -centimeter. Tanks U3 
and $U 4$ are located in the western half of $U$ Cel1, the acid storage vauit, which is located external of the PUREX Plant canyon area along the north wall of the PUREX Plant. The $U$ Cell is constructed primarily below ground level with a removable concrete cover block roof at about 0.3 -meter above ground level. Ancillary equipment for tanks U3 and U4 includes the following:

- Drain piping (304L stainless steel) from laboratory sinks and hoods

- Transfer piping (304L stainless steel) from drain Tines to tanks U3 and U4, and from tanks U3 and U4 to sumps SUA and SUB

- Overflow piping (304L stainless steel) that interconnect tanks U3 and $\mathrm{U}_{4}$

- Discharge piping (304L stainless steel) from tanks U3 and U4, through the north wall of the PUREX Plant adjacent to $U$ Cell, across the ceiling of the storage gallery, through the PUREX Plant canyon wall, across D Cell, into the hot pipe trench, and back to D Cell

- Jumper (304L stainless steel) in D Cell that connects the discharge piping from tanks U3 and U4 to discharge piping in the hot pipe trench that leads out of the PUREX Plant

- Discharge piping (304L stainless stee1) from the jumper in D Cell, through the hot pipe trench, out the south side of the PUREX Plant, to the 241-A-151 diversion box.

Tanks U3 and U4 were placed in service in 1956.

2.2.1.6 Tanks Q21 and Q22 (Q Ce11 aqueous makeup tanks). Tanks Q21 and Q22 are cylindrical, 81- and 968-1iter, respectively, capacity 304L stain less steel tanks located in the Q Cell aqueous makeup unit (AMU). Tank Q21 is 45.7 centimeters in diameter and 61 centimeters taTl. Tank Q22 is 106.7 centimeters in diameter and 121.9 centimeters ta11. The $Q$ Cell AMU is located in the west end of the storage gallery, on the second level of $Q$ Cell. Ancillary equipment for tanks Q21 and Q22 are outlet Tines (304L stainless steel) to the vessel vent header and tank Q5.

\subsubsection{PUREX Plant Containment Building}

The solid mixed waste storage areas located in the PUREX Plant consist of a section of the canyon deck adjacent to $\mathrm{D}$ Cell and the $\mathrm{F} 17$ position in $\mathrm{F}$ Cell. These storage areas are considered to be in a 'containment building' subject to the requirements of 40 CFR 265, Subpart DD. The solid mixed waste stored on the canyon deck, consisting of lead and cadmium, was moved to PUREX Storage Tunnel Number 2 as part of transition phase activities. The solid mixed waste in $F$ Cell consists mainly of concrete and tank dunnage corrosion products. A qualified registered professional engineer has certified that the PUREX Plant canyon area meets the required design standards as specified in 40 CFR 265.1101(a) (Giller 1992). 
Limited activities are planned for the containment building as part of the preclosure work plan.

\subsection{SECURITY INFORMATION}

The entire Hanford Facility is a controlled-access area. The Hanford Facility maintains around-the-clock surveillance for the protection of government property, classified information, and special nuclear materials. The Hanford Patrol maintains a continuous presence of protective force personnel to provide additional security. All personnel accessing Hanford Facility areas must have a DOE-issued security identification badge indicating the appropriate authorization. Personnel also could be subject to a random search of items carried into or out of the Hanford Facility.

Hanford Facility personnel receive training on security regulations in the form of required security education and on-the-job training. Methods for ensuring personnel compliance with security requirements and provisions for security training are maintained on the Hanford Facility. 


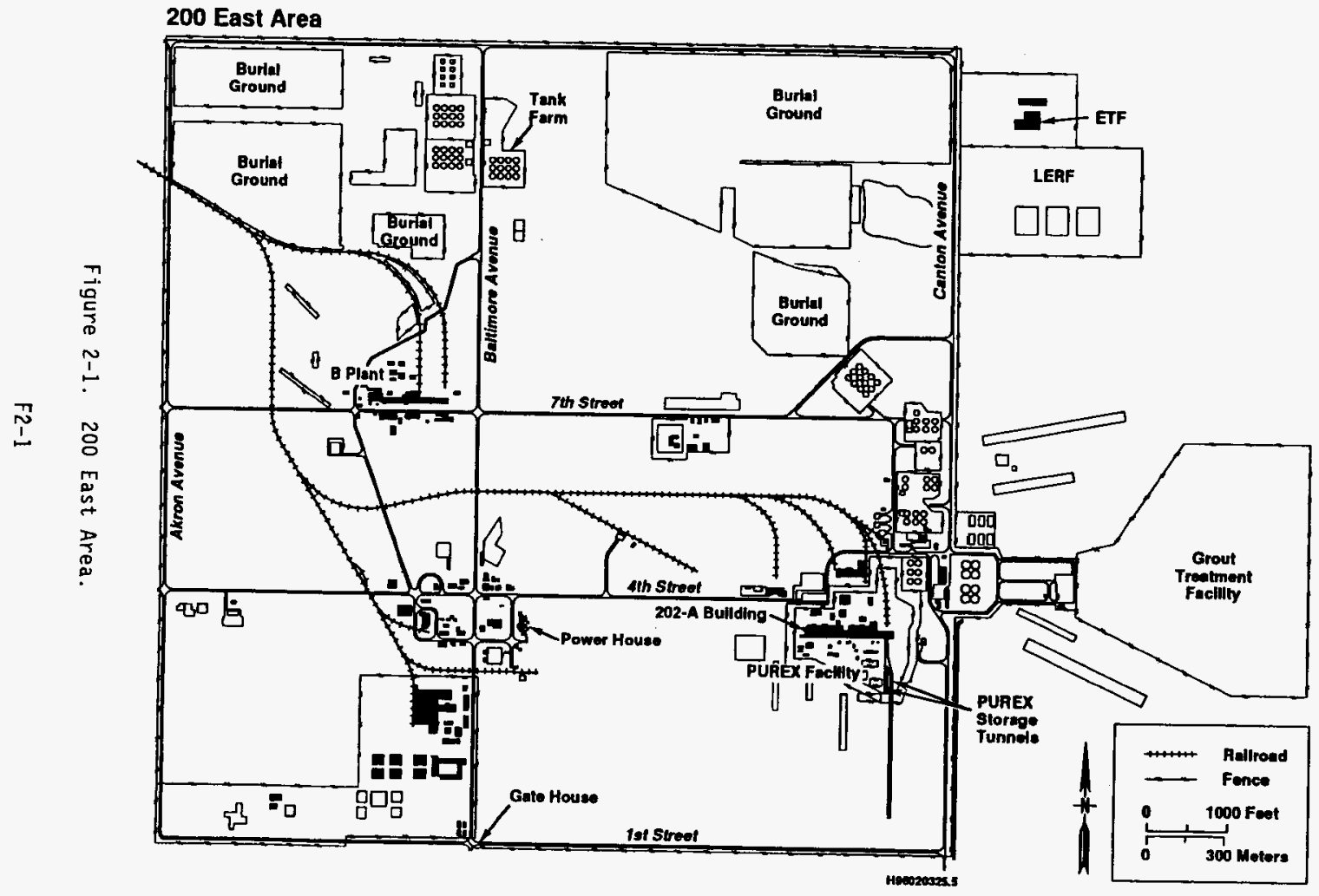


THIS PAGE INTENTIONALLY

LEFT BLANK. 


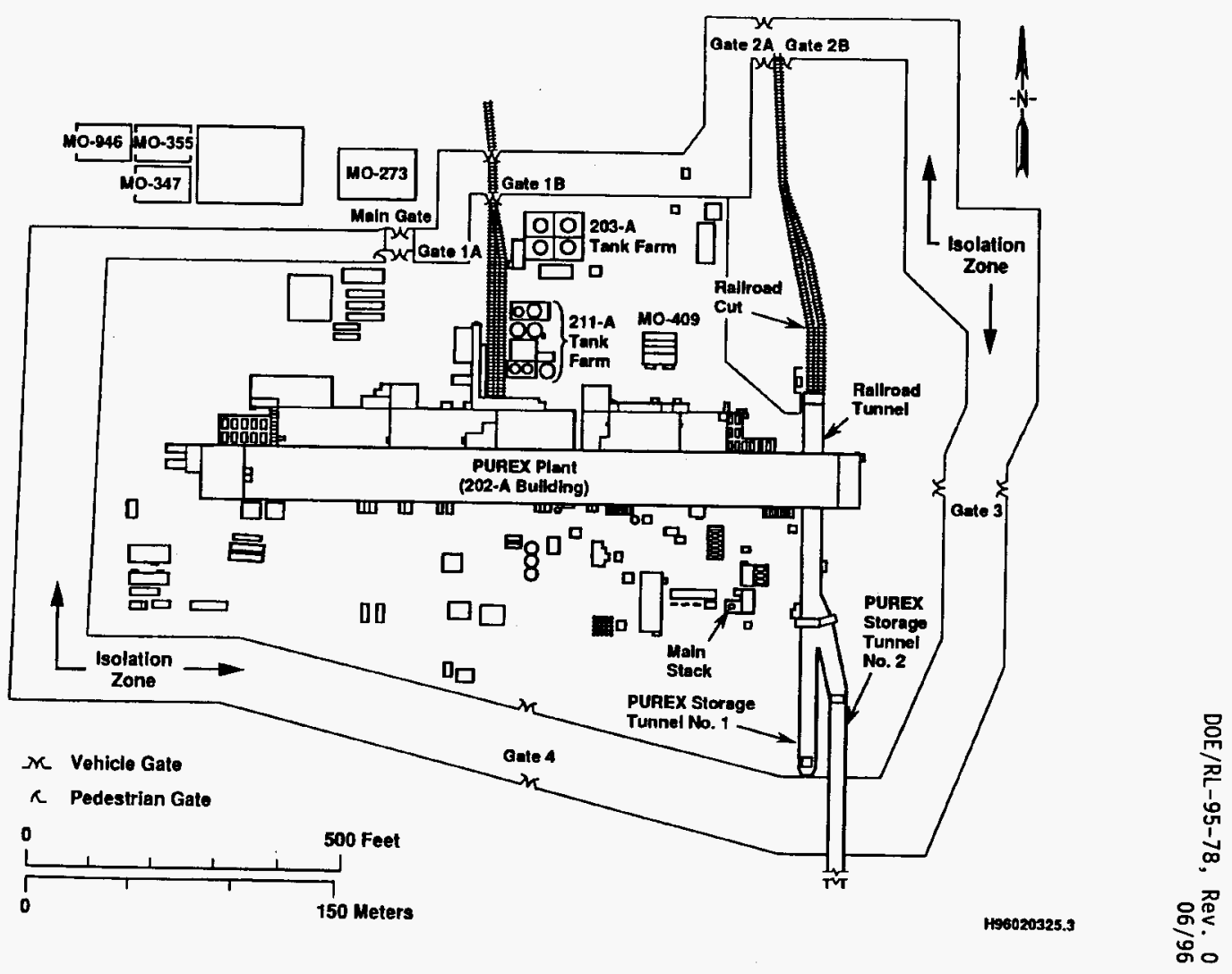


TWOA PAGE MIENTIONALLY

LEFT BLANK. 

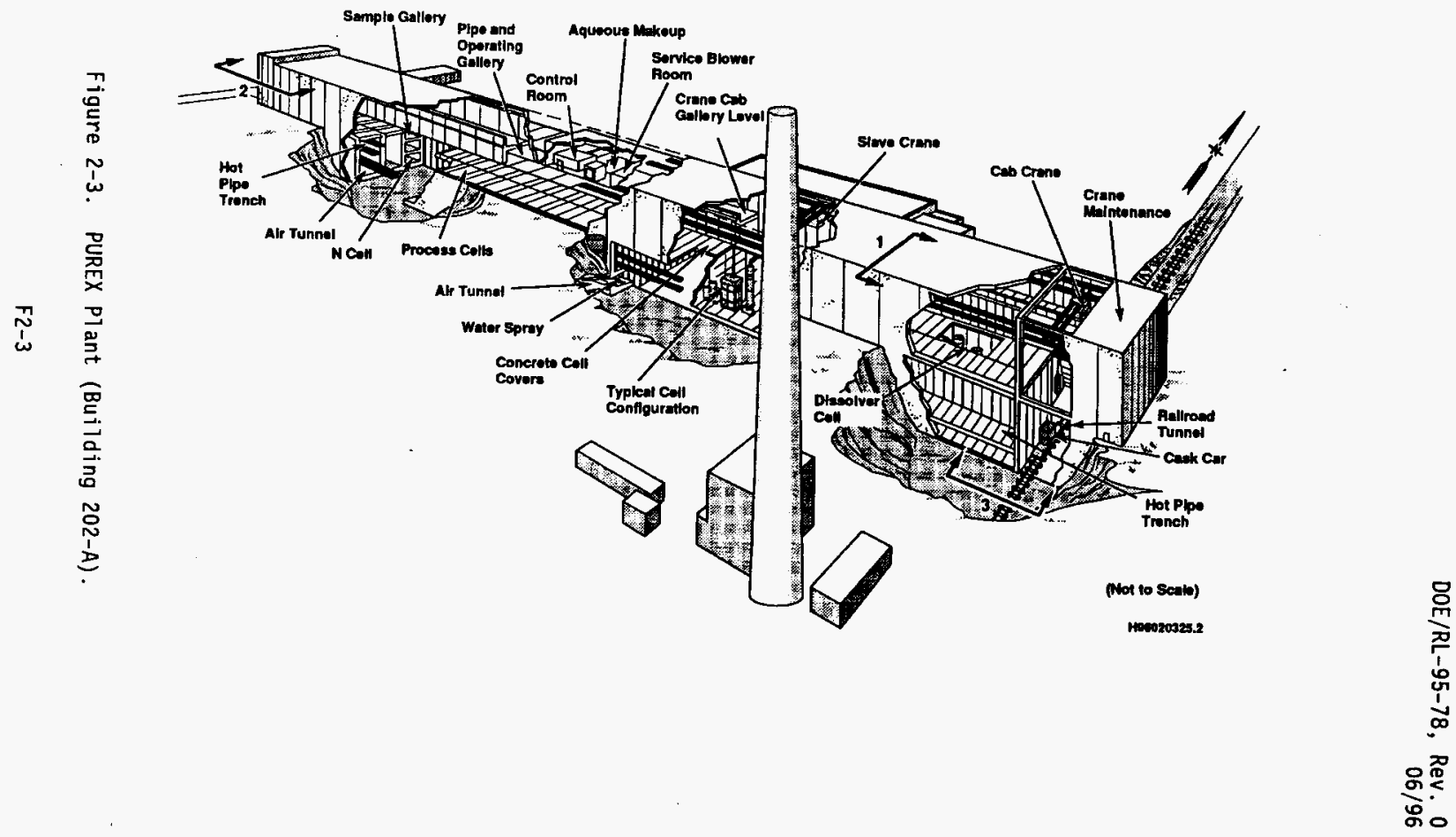


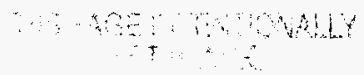


DOE/RL-95-78, Rev. 0 06/96

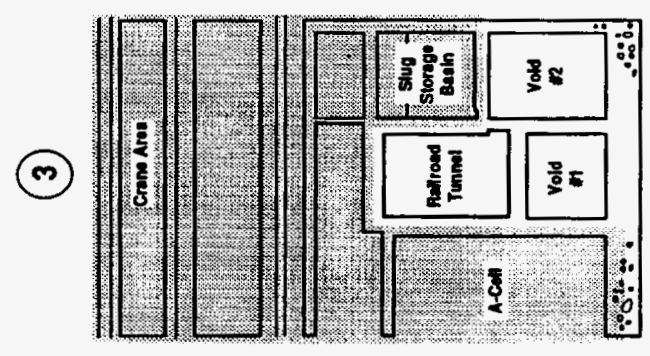

롫
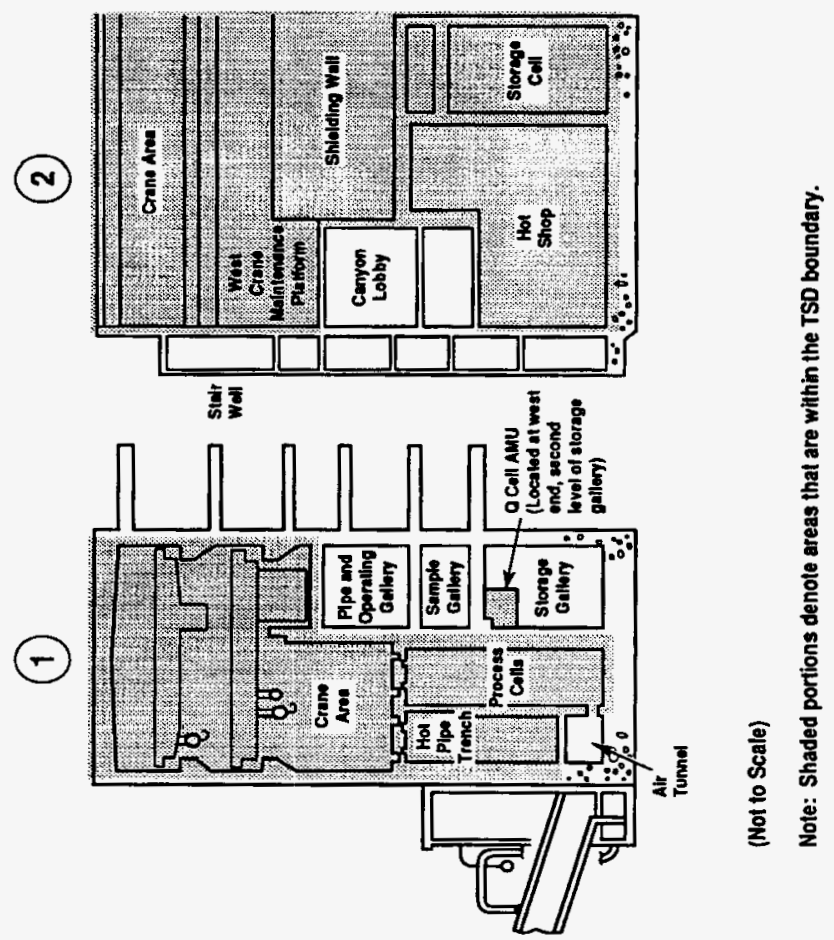

Figure 2-4. PUREX Plant Cross-Section (looking west). 


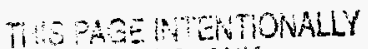
EET BLANK. 


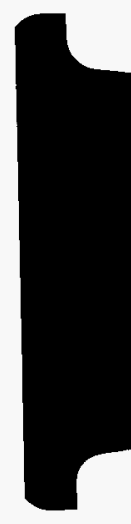




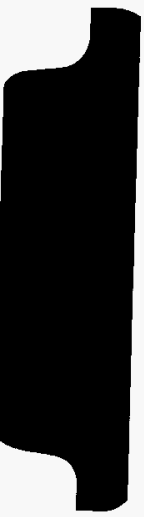


3.0 PROCESS INFORMATION ................... . . . . .

3.1 PUREX PROCESS DESCRIPTION . . . . . . . . . . . 3-1

3.2 VESSEL SYSTEMS .................. . . . . . .

3.2.1 Cladding Removal Waste Treatment System ..... 3-1

3.2.2 Neutralized Zirflex Acid Waste Treatment System . . . 3-2

3.2.3 Miscellaneous Mixed Waste Treatment System . . . . . 3-3

3.2.4 Headend Ammonia Waste Treatment System . . . . . . . 3-3

3.2.5 Misce17aneous Headend Treatment System . . . . . . . 3-4

3.3 TRANSITION PHASE VesSEL SYSTEMS ............ . . 3-5

3.4 PUREX PLANT CONTAINMENT BUILDING ............. .5

3-1. E-F1l and Tank E5 Waste Stream (before August 1987) . . . . . . . . F3-1

3-2. Tanks F15 and F16 Waste Stream . . . . . . . . . . . . . . . . F3-2

3-3. Tank F18 Waste Stream . . . . . . . . . . . . . . . . . . . F3-3

3-4. E-F1l and Tank E5 Waste Stream (August 1987 to Deactivation) . . . F3-4

3-5. Tanks U3 and U4 Waste Stream ................. F3-5

\section{TABLE}

3-1. PUREX Plant Process and Chemical Additions . . . . . . . . . . . T3-1 
D0E/RL-95-78, Rev. 0

06/96

This page intentionally left blank. 


\subsection{PROCESS INFORMATION}

This chapter describes the waste streams and the waste treatment systems associated with the PUREX process.

\subsection{PUREX PROCESS DESCRIPTION}

Irradiated reactor fuel was processed to extract, purify, and concentrate uranium, plutonium, and neptunium produced from the reactor fuel. The main process components provided for the chemical decladding and dissolution of the fuel elements, and separation and purification of uranium, plutonium, and neptunium by solvent extraction. Process support systems recovered and stored nitric acid and organic solvents, and provided other treatment and storage of gaseous, liquid, and solid waste.

\subsection{VESSEL SYSTEMS}

Waste treatment conducted in vessel systems in the PUREX P1ant made 1iquid waste generated during the PUREX process acceptable for storage in the DST System (DOE/RL-90-39). The corrosion acceptance criteria of the DST System includes a $\mathrm{pH}$ greater than 12.0 and a nitrite concentration greater than $0.011 \mathrm{M}$. Genera17y, the treatment involved raising the $\mathrm{pH}$ with sodium hydroxide $(\mathrm{NaOH})$ and adding sodium nitrite $\left(\mathrm{NaNO}_{2}\right)$ to obtain the necessary conditions to inhibit corrosion of the carbon steel tanks in the DST System. The following sections discuss the processes and the vessels associated with each process. Table 3-1 lists all permitted vessels, their associated process, and chemical additions made during processing.

\subsubsection{Cladding Removal Waste Treatment System}

Three types of mixed waste streams were generated during decladding operations. These three mixed waste streams, collectively called cladding removal waste $(C R W)$, include the following.

- Decladding waste--This waste was generated when the zirconium cladding was removed from the irradiated fuel elements. Ammonium fluorideammonium nitrate (AFAN) dissolved the fuel cladding by complexing the zirconium metal jacket, leaving the uranium, plutonium, and neptunium metal in the dissolver.

- Spent metathesis waste--After the zirconium was removed from the fuel rods, uranium and plutonium fluoride compounds generated during decladding operations were metathesized using a solution of potassium hydroxide. The spent potassium hydroxide solution constituted the metathesis waste. 
- Metathesis rinse waste--Water was added to the dissolvers to rinse the remaining metathesis solution from the fuel and to dilute the residual metathesis solution and decladding solution that remained in the heel. The resulting solution constituted the metathesis rinse waste.

Al1 three CRW mixed waste streams were jetted to tank E5 for treatment (Figure 3-1). Before being transferred to tank E5, the decladding and metathesis waste solutions were transferred from tank E3 to one of two centrifuges (E2 and E4) to remove residual plutonium and uranium solids. This recovery process was intended solely to recover plutonium and uranium product and was not a dangerous waste treatment activity.

Decladding waste was treated by adding $\mathrm{NaOH}$ and $\mathrm{NaNO}_{2}$ to the waste in tank E5 to meet the DST System corrosion specifications. The line to the DST System was flushed with water after waste transfers.

The decladding waste treatment reaction caused approximately 10 to 20 percent of the ammonia in solution to be released. Ammonia gas was scrubbed from the offgas treatment system and treated (Section 3.2.4).

Metathesis waste normally arrived at tank $\mathrm{E5}$ with a $\mathrm{pH}$ greater than 12 , which met the DST System $\mathrm{pH}$ specifications. The waste was sampled and sodium nitrite was added. Sodium hydroxide was added only if the $\mathrm{pH}$ was below the DST System specifications. The transfer to the DST System was followed by a water flush.

Metathesis rinse waste was treated in a manner similar to the decladding waste in that $\mathrm{NaOH}$ and $\mathrm{NaNO}_{2}$ were added to tank E5. The treated waste was sampled before being transferred to the DST System, and the line was flushed with water.

\subsubsection{Neutralized Zirflex Acid Waste Treatment System}

Tanks F15 and F16 were used to treat highly radioactive, concentrated acid solutions, known as neutralized zirflex acid waste (NZAW), generated from the solvent extraction process. The NZAW contained the waste fission products separated from the first decontamination cycle.

The NZAW was received in tank F15 in approximately 9,800-7iter batches for treatment (Figure 3-2). The solution was sampled and, if the solution did not have to be reworked because of high plutonium content, the solution was declared waste, heated, and treated with a sugar (sucrose) solution, which was added to the tank over a 16- to 24-hour period. The resuiting reaction between the nitric acid and the sugar solution produced oxides of nitrogen $\left(\mathrm{NO}_{\mathrm{x}}\right)$ and carbon, and oxides of carbon $\left(\mathrm{CO}_{x}\right)$. These offgases were routed to the $\mathrm{F} 5$ acid absorber where approximately 25 percent of the $\mathrm{NO}_{x}$ was recovered as nitric acid for reuse in the process.

After initial treatment in tank F15, the NZAW was transferred to tank F16. Sugar denitration was completed, if necessary, and the waste was treated with $\mathrm{NaOH}$ and $\mathrm{NaNO}_{2}$, sampled, and transferred to the DST System. 


\subsubsection{Miscellaneous Mixed Waste Treatment System}

Tank F18 received miscellaneous mixed waste solutions from the following areas: canyon cell floor sumps; drainage from the vessel vent system, condenser vent system, and sampier headers; hot shop maintenance cell solutions; sample gallery floor drains; and bottoms from E-Fll. Solutions were pumped or jetted to tank F18 from their point of origin (Figure $3-3$ ). Transfer piping is located in the reinforced concrete hot pipe trench.

Before receiving solutions in tank F18, the heel had to be acidified (at least $0.3 \mathrm{M}$ nitric acid) to keep plutonium and uranium nitrates from precipitating. Keeping these compounds in solution was necessary to allow for representative sampling for nuclear material accountability and was required to meet a criticality specification.

Once the heel had been acidified, solutions could be received in tank F18. Samples were taken when the level in tank F18 reached 13,200 to 15,100 liters. If the contents of tank F18 did not have to be reworked because of high plutonium concentrations, the solution was declared waste, appropriate amounts of $\mathrm{NaOH}$ and $\mathrm{NaNO}_{2}$ were added, and the waste was sent to the DST System.

\subsubsection{Headend Ammonia Waste Treatment System}

A solution of AFAN was used in the dissolvers to chemically declad zirconium-clad fuel from $N$ Reactor (Section 3.2.1). During the decladding operation, ammonia was scrubbed from the offgases by water to form an aqueous ammonium hydroxide solution.

During fuel decladding and solids metathesis, approximately 70 percent of the ammonium compounds charged to the dissolvers were evolved as ammonia gas, most of which was absorbed in dissolver condensate or scrubbed from the dissolver offgas with water. The remaining ammonia remained in the CRW until treated in tank E5 and transferred to the DST System. During treatment of the cladding removal waste in tank E5, approximately 10 to 20 percent of the ammonium ion content was released as ammonia gas, which was scrubbed with water. The ammonia scrubber solutions from the three dissolver offgas systems and the $E$ CelT operations were combined. This stream contained ammonium hydroxide and low levels of radionuclides.

Before August 1987, the ammonia scrubber waste solution was concentrated in E-FIl in $\mathrm{F} \mathrm{Cell} \mathrm{to} \mathrm{remove} \mathrm{carry-over} \mathrm{waste} \mathrm{fission} \mathrm{products,} \mathrm{and} \mathrm{the}$ overhead condensate was discharged to 216-A-36B crib (Figure 3-1). The ammonia scrubber waste treatment process was rerouted to transfer the ammonia solution to the DST System.

The ammonia generated in the headend dissolvers was scrubbed from the offgas and the scrub solution was collected in catch tanks A3-4, B3-4, and C3-4 and combined with the aqueous discharge from the E Cell ammonia offgas scrubber in accumulation tank F12. After the ammonia scrubber system was rerouted, the ammonia waste collected in tank F12 was transferred to 
tank G7. Chemical additions were made to adjust pH and nitrite concentration to DST System specifications (Figure 3-4). The treated waste was transferred to the DST System.

The E-FI1 concentrator was used during PUREX PIant transition phase to evaporate some of the flush solution waste water normaliy sent to the DST System. The distillate (nonregulated) was discharged to the atmosphere via the PUREX Plant main stack (291-A-1). The concentrate generated in E-FII was treated with $\mathrm{NaOH}$ and $\mathrm{NaNO}_{2}$ in tank F18 before being transferred to the DST System.

\subsubsection{Miscellaneous Headend Treatment System}

Tanks U3 and U4 (Figure 3-5), located in the western half of $U$ Cell, received miscellaneous mixed waste solutions from the headend (reactor fuel receiving and dissolution portion). Waste sources, both regulated and nonregulated, include the following:

- Washdown (radiological decontamination) of railcars in the railroad tunnel via floor drains and sump collection system

- Analytical laboratory sink and hood drains

- 206-A Fractionator Building sumps

- Drain from the 291-A-1 main stack

- Various analytical laboratory heating, ventilation, and air conditioning vent drains

- U Cell sumps SUA and SUB

- Other tank systems on a case-by-case basis.

The most diversified categories of dangerous waste received into tanks U3 and $\mathbf{U} 4$ originated from the analytical laboratory. However, the combined quantities of these various dangerous waste components was only a small (estimated to be less than 5 percent) fraction of the total volume of mixed waste stored and treated in this tank system.

The majority of the waste stream received in tanks U3 and U4 was nonregulated, potential radioactively contaminated water and was jetted or pumped from the point of generation to either tank U3 or U4. An exception was waste (from the analytical 1aboratory) that drained by gravity from the laboratory area to one of the vesseis. The standard activity was to fill one tank, sample and treat the waste in that tank while the other tank began to fi1l. Thus, each tank in turn received and treated miscellaneous dangerous waste. 
As with the liquid waste treated in the waste tanks described in the preceding sections, 'treatment' of the miscellaneous headend waste was done solely to address the corrosive characteristic of the waste so the waste would be compatible with the carbon steel containment of the DST System. To comply with the waste acceptance criteria of the DST System, the waste was treated with $\mathrm{NaOH}$ to adjust the $\mathrm{pH}$ and $\mathrm{NaNO}_{2}$ to meet the nitrite requirements.

\subsection{TRANSITION PHASE VESSEL SYSTEMS}

During the transition phase, tanks Q21 and Q22 were permitted for treatment and storage when the tanks were found to contain corrosive solutions. The treatment in tanks Q21 and Q22 consisted of a one-time addition of $\mathrm{NaOH}$ to neutralize the corrosive solutions. These tanks were not flushed or sampled because both tanks have bottom drains, which left no heel. The tanks were drained to tank F18 and the waste transferred to the DST System.

An additional 35 vessels were permitted for storage during transition activities, when a determination was made that corrosive solutions had been stored in the vessels. These vessel systems were drained, or flushed and sampled, and the waste transferred to the DST System.

\subsection{PUREX PLANT CONTAINMENT BUILDING}

Since December 7, 1987, discarded, contaminated process equipment removed from the canyon area, which contained lead and cadmium, has been stored on the hot pipe trench side of the canyon deck adjacent to $D$ Cell. To date, the location of the stored mixed waste has been administratively restricted to the area adjacent to $\mathrm{DCe} 11$, and inside $\mathrm{F}$ CeIl (F17 position). As part of transition phase activities, the mixed waste stored on the canyon deck adjacent to $\mathrm{D}$ Cell has been moved to PUREX Storage Tunnel Number 2.

The waste stored in position F17 within $F$ Cell consists of concrete debris collected from the floor of $\mathrm{E} C \mathrm{Cll}$. The concrete material was retrieved from the floor during the replacement of tank E3. The debris, approximately 1.0 cubic meters and weighing approximately 4,100 kilagrams, is contained in a $1.2 \times 1.8 \times 0.6$-meter carbon steel scrap hopper (skip). The debris contains regulated quantities of chromium and approximately 400 grams of plutonium. The estimated dose rate of the skip is $500 \mathrm{Rad} / \mathrm{hour}$.

Weekly surveillance of the air pressure differential between the inside and the outside of the containment building fulfills the 'inspection' requirements [ 40 CFR $265.1101(\mathrm{c})(4)$ ]. The canyon area is maintained at a negative air pressure compared to ambient air pressure. The existence of an air pressure differential between the inside and outside of the structure verifies that no large openings exist in the building. In the event that small openings in the building were present, the flow of air would be inward. These factors ensure that adequate containment exists. 
DOE/RL-95-78, Rev. 0

06/96

This page intentionally left blank.

THS PHE NTENTIONALLY

LEFT BLANK. 


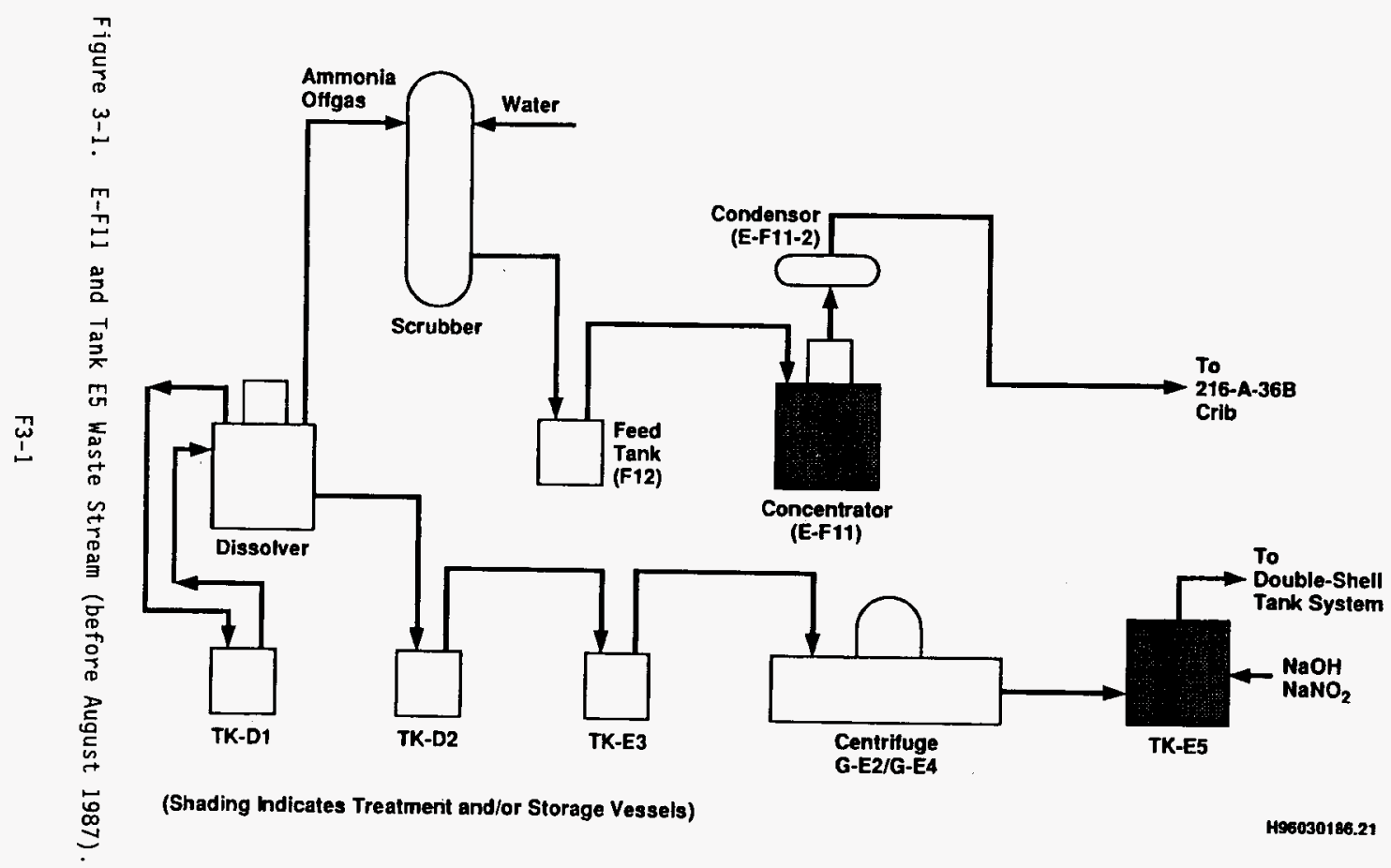


THIS PAOEINIENTIONALLY

LEFT BLANK. 


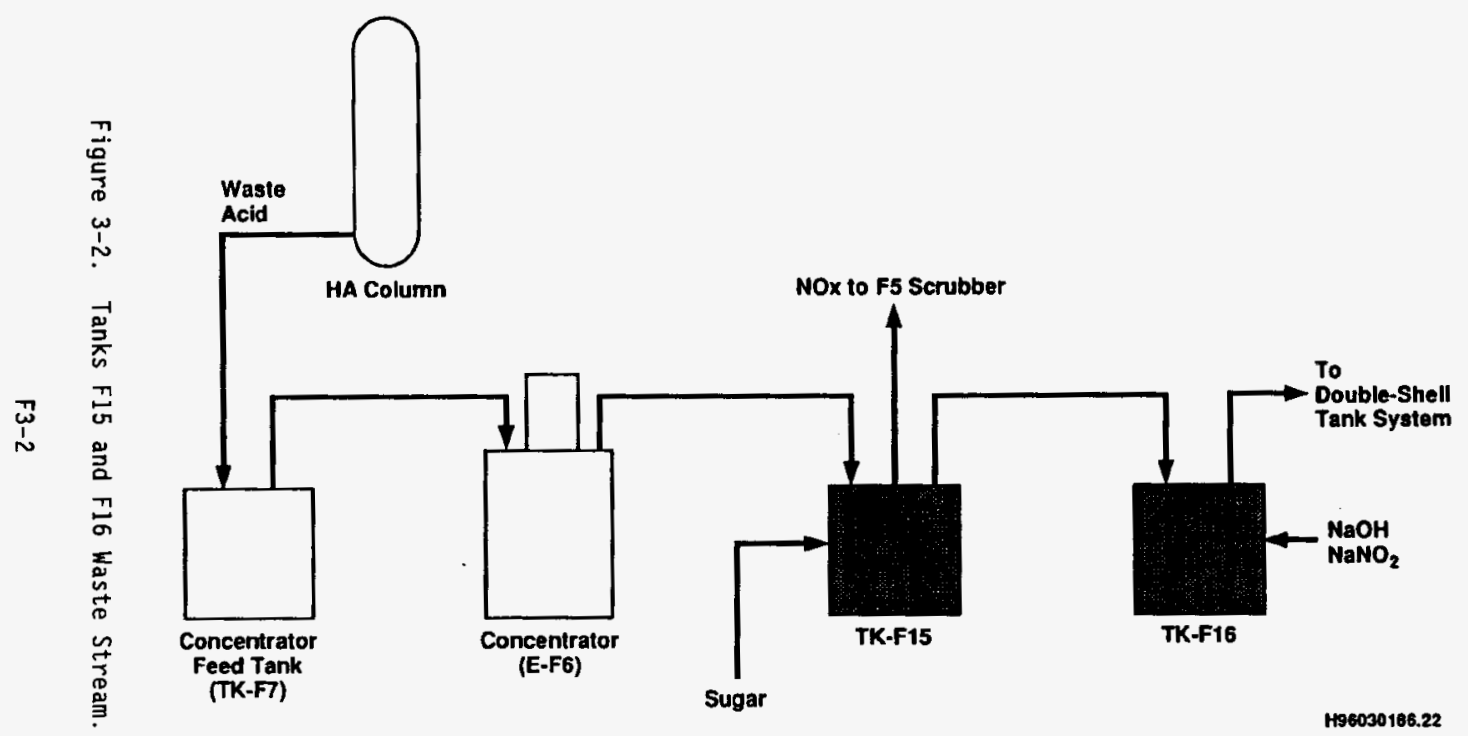

(Shading Indicates Treatment and/or Storage Vessels) 
THIS PEGE NTENTIONALLY LEFT BLANK. 
DOE/RL-95-78, Rev. 0

$06 / 96$

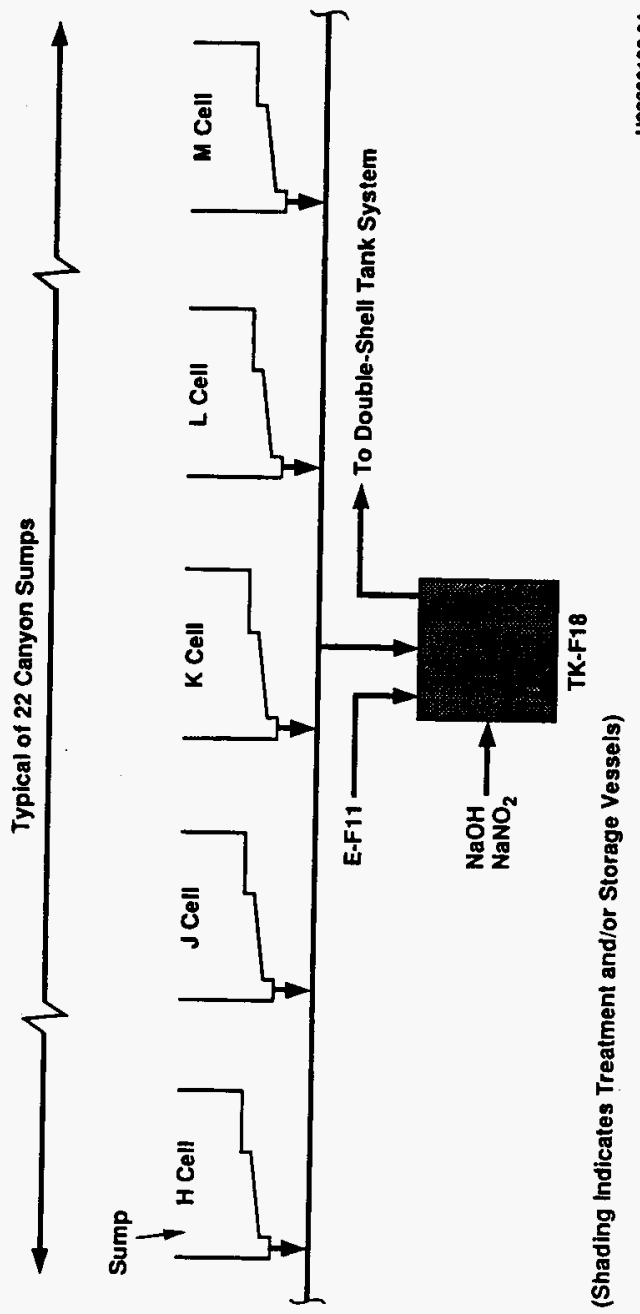

Figure 3-3. Tank F18 Waste Stream. 


\section{MS OAGE NTENTIONALLY LEFT BLANK.}


:

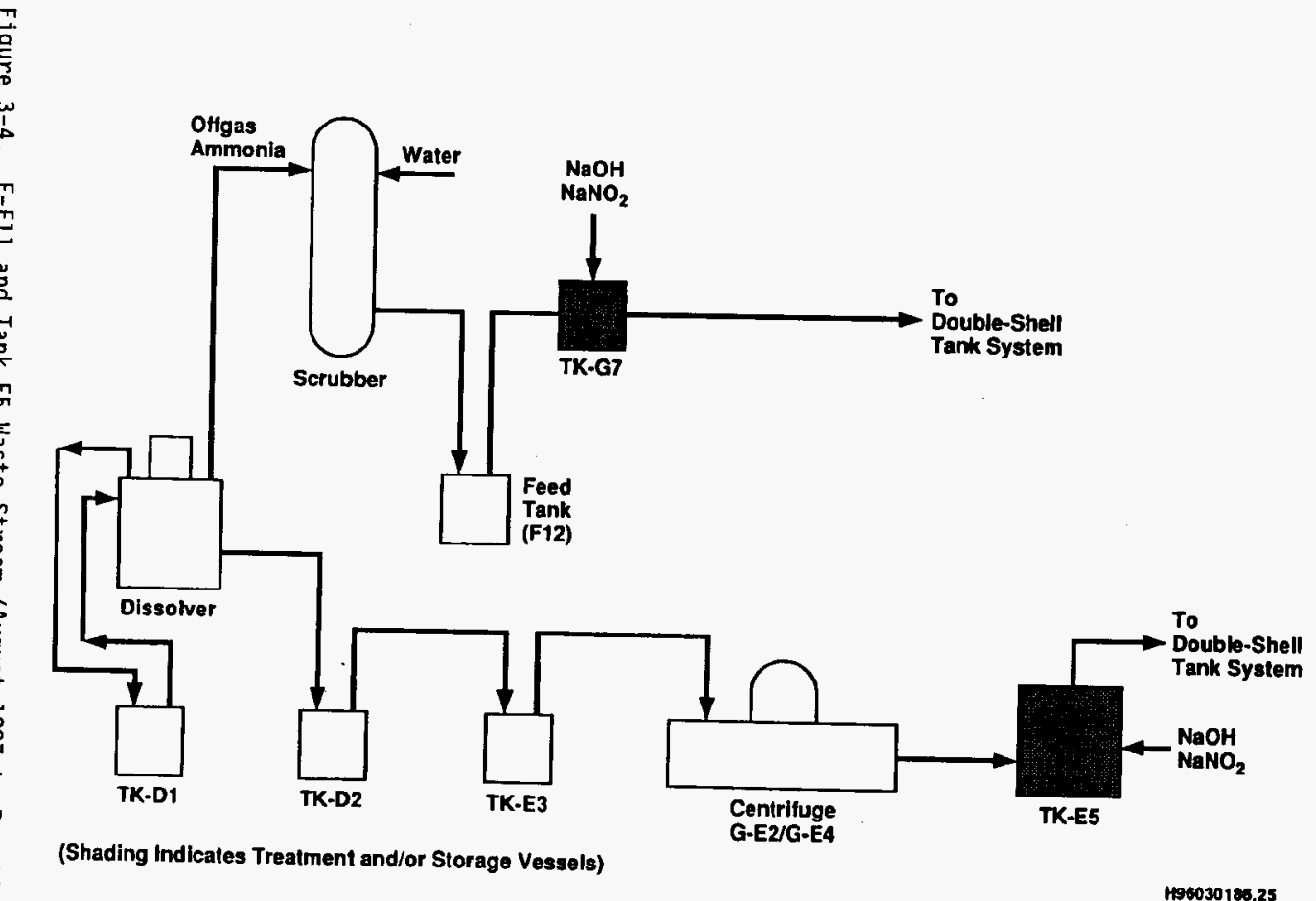

H96030183.25 
THS PAGE INTENTIONALLY IFET BLANK. 


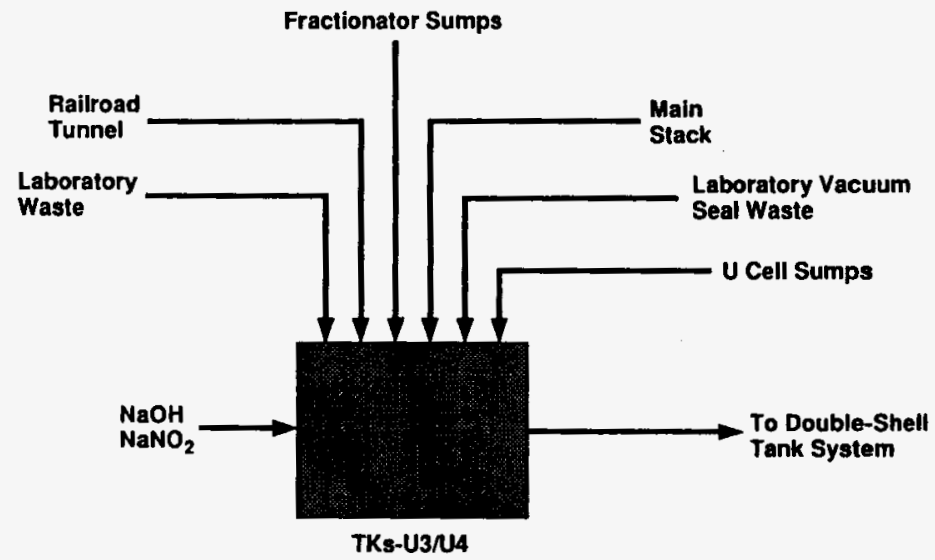

(Shading Indicates Treatment and/or Storage Vessels)

H96030196.27 
THIS PAGE INTENTIONALLY LEFT BLANK. 
Table 3-1. PUREX Plant Process and Main Chemicals. (sheet 1 of 2)

\begin{tabular}{|c|c|c|c|}
\hline Vessel & Process & & Main chemicals \\
\hline $\begin{array}{l}\text { Tk-D5 } \\
\text { Tk-E6 }\end{array}$ & $\begin{array}{l}\text { Metal dissolution } \\
\text { and feed } \\
\text { preparation }\end{array}$ & $\begin{array}{l}\mathrm{ANN} \\
\mathrm{HNO}_{3}\end{array}$ & $\begin{array}{l}\text { aluminum nitrate nonahydrate } \\
\text { nitric acid }\end{array}$ \\
\hline$E-F 11$ & $\begin{array}{l}\text { Dissolver offgas } \\
\text { treatment and } \\
\text { ammonia scrubber } \\
\text { waste } \\
\text { concentration }\end{array}$ & $\mathrm{NH}_{3} \mathrm{OH}$ & ammonium hydroxide \\
\hline Tk-E5 & $\begin{array}{l}\text { Cladding waste } \\
\text { cycle }\end{array}$ & $\begin{array}{l}\text { AFAN } \\
\text { ANN } \\
\mathrm{KOH} \\
\star \mathrm{NaOH} \\
* \mathrm{NaNO}_{2} \\
\end{array}$ & $\begin{array}{l}\text { ammonium fluoride/ammonium nitrate } \\
\text { aluminum nitrate nonahydrate } \\
\text { potassium hydroxide } \\
\text { sodium hydroxide } \\
\text { sodium nitrite }\end{array}$ \\
\hline $\begin{array}{l}T \mathrm{~T}-\mathrm{HI} \\
T-\mathrm{H} 2 \\
T \mathrm{k}-\mathrm{J3} \\
T-\mathrm{J} 6 \\
T-\mathrm{J} 7\end{array}$ & $\begin{array}{l}\text { Decontamination } \\
\text { and } \\
\text { partition cycle }\end{array}$ & $\begin{array}{l}\mathrm{NaNO}_{2} \\
\mathrm{NPH} \\
\mathrm{TBP} \\
\mathrm{HNO} \\
\mathrm{Fe}\left(\mathrm{NH}_{2} \mathrm{SO}_{3}\right)_{2} \\
\mathrm{NH}_{2} \mathrm{SO}_{3} \mathrm{H} \\
\end{array}$ & $\begin{array}{l}\text { sodium nitrite } \\
\text { normal paraffin hydrocarbon } \\
\text { tri-butyl phosphate } \\
\text { nitric acid } \\
\text { ferrous sulfamate } \\
\text { sulfamic acid }\end{array}$ \\
\hline $\begin{array}{l}T k-K 1 \\
T-K 2 \\
T-K 3 \\
T k-K 6\end{array}$ & Uranium cycle & $\begin{array}{l}\mathrm{NPH} \\
\mathrm{TBP} \\
\mathrm{N}_{2} \mathrm{H}_{4} \\
\mathrm{HNO}_{3} \\
\mathrm{HN}\end{array}$ & $\begin{array}{l}\text { normal paraffin hydrocarbon } \\
\text { tri-butyl phosphate } \\
\text { hydrazine } \\
\text { nitric acid } \\
\text { hydroxylamine nitrate }\end{array}$ \\
\hline $\begin{array}{l}T-L 2 \\
T K-L 3 \\
T-L 4\end{array}$ & Plutonium cycle & $\begin{array}{l}\mathrm{NPH} \\
\mathrm{TBP} \\
\mathrm{NaNO}_{2} \\
\mathrm{HNO}_{3} \\
\mathrm{~N}_{2} \mathrm{H}_{4} \\
\mathrm{HN}\end{array}$ & $\begin{array}{l}\text { normal paraffin hydrocarbon } \\
\text { tri-butyl phosphate } \\
\text { sodium nitrite } \\
\text { nitric acid } \\
\text { hydrazine } \\
\text { hydroxylamine nitrate }\end{array}$ \\
\hline $\begin{array}{l}T k-j 21 \\
T-J 22 \\
T-J 23 \\
T k-021 \\
T k-022\end{array}$ & $\begin{array}{l}\text { Neptunium } \\
\text { recovery and } \\
\text { purification } \\
\text { cycle }\end{array}$ & $\begin{array}{l}\mathrm{NPH} \\
\mathrm{TBP} \\
\mathrm{N}_{2} \mathrm{H}_{4} \\
\mathrm{Fe}_{4}\left(\mathrm{NH}_{2} \mathrm{SO}_{3}\right)_{2} \\
\mathrm{HNO}_{3} \\
\mathrm{HN}\end{array}$ & $\begin{array}{l}\text { normal paraffin hydrocarbon } \\
\text { tri-butyl phosphate } \\
\text { hydrazine } \\
\text { ferrous sulfamate } \\
\text { nitric acid } \\
\text { hydroxylamine nitrate }\end{array}$ \\
\hline $\begin{array}{l}E-H 4 \\
T k-J 1\end{array}$ & $\begin{array}{l}\text { Backcycle waste } \\
\text { system }\end{array}$ & $\mathrm{HNO}_{3}$ & nitric acid \\
\hline
\end{tabular}


THIS PAGE MTENTIONALLY LEFT BLANK. 
Table 3-1. PUREX Plant Process and Main Chemicals. (sheet 2 of 2)

\begin{tabular}{|c|c|c|c|}
\hline Vessel & Process & & Main chemicals \\
\hline $\begin{array}{l}T k-G 1 \\
T k-G 2 \\
T-G 2 \\
T k-G 5 \\
T k-G 8 \\
T k-R 1 \\
T k-R 2 \\
T-R 2 \\
T k-R 7\end{array}$ & Solvent recovery & $\begin{array}{l}\mathrm{NPH} \\
\mathrm{TBP} \\
\mathrm{Na}_{2} \mathrm{CO}_{3} \\
\mathrm{KMnO}_{4} \\
\mathrm{HNO}_{3} \\
\mathrm{NaNO}_{2} \\
\mathrm{NaOH}^{2}\end{array}$ & $\begin{array}{l}\text { normal paraffin hydrocarbon } \\
\text { tri-butyl phosphate } \\
\text { sodium carbonate } \\
\text { potassium permanganate } \\
\text { nitric acid } \\
\text { sodium nitrite } \\
\text { sodium hydroxide }\end{array}$ \\
\hline $\begin{array}{l}\text { Tk-F15 } \\
\text { Tk-F16 } \\
\text { Tk-F18 }\end{array}$ & $\begin{array}{l}\text { Waste } \\
\text { concentration and } \\
\text { treatment }\end{array}$ & $\begin{array}{l}\text { Sugar } \\
{ }^{*} \mathrm{NaOH} \\
\mathrm{NaNO}_{2} \\
\mathrm{ANN}_{2} \\
\mathrm{HNO}_{3}\end{array}$ & $\begin{array}{l}\text { sodium hydroxide } \\
\text { sodium nitrite } \\
\text { aluminum nitrate nonahydrate } \\
\text { nitric acid }\end{array}$ \\
\hline $\begin{array}{l}\text { Tk-F3 } \\
\text { Tk-F4 } \\
\text { T-F5 } \\
\text { Tk-U3 } \\
\text { Tk-U4 }\end{array}$ & Acid recovery & $\begin{array}{l}\text { ANN } \\
\mathrm{HNO}_{3}\end{array}$ & $\begin{array}{l}\text { aluminum nitrate nonahydrate } \\
\text { nitric acid }\end{array}$ \\
\hline Tk-156 & Aqueous makeup & $\mathrm{HNO}_{3}$ & nitric acid \\
\hline Tk-P4 & $\begin{array}{l}\text { Uranium Storage } \\
\text { Tanks } \\
\text { (203-A Tank Farm) }\end{array}$ & $\begin{array}{l}\mathrm{UNH} \\
\mathrm{HNO}_{3}\end{array}$ & $\begin{array}{l}\text { uranyl nitrate hexahydrate } \\
\text { nitric acid }\end{array}$ \\
\hline$T k-40$ & $\begin{array}{l}\text { Chemical Tanks } \\
\text { (211-A Tank Farm) }\end{array}$ & $\begin{array}{l}\mathrm{NPH} \\
\mathrm{TBP}\end{array}$ & $\begin{array}{l}\text { normal paraffin hydrocarbon } \\
\text { tri-buty1 phosphate }\end{array}$ \\
\hline Tk-G7 & $\begin{array}{l}\text { Effluent } \\
\text { discharge systems }\end{array}$ & $\begin{array}{l}\mathrm{KOH} \\
\mathrm{KaOH} \\
\mathrm{NaNO}_{2}\end{array}$ & $\begin{array}{l}\text { temporary } \\
\text { temporary } \\
\text { temporary }\end{array}$ \\
\hline TK-M2 & Other & $\mathrm{HNO}_{3}$ & nitric acid \\
\hline
\end{tabular}

- Chemicals added only when solution was transferred to DST System (i.e., PDD, ASD effluent streams). 
THIS PAGE INTENTIONALLY LEFT B'ANK. 



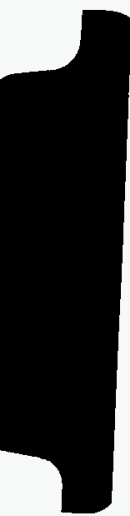




\section{CONTENTS}

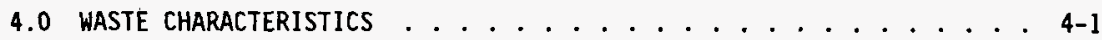

4.1 VESSEL SYSTEMS ....................... . . .

4.2 CONTAINMENT BUILding .................... . . . .

FIGURES

4-1. Flush K Cell Vessels ................... F4-1

4-2. Flush $L$ Cell Vessels . . . . . . . . F4-2

4-3. Flush Headend Feed Vessels, $\mathrm{HI}, \mathrm{H2}$, and $\mathrm{F}$ Cell Vessels .... F4-3

4-4. Flush $G$ and $R$ Cell Vessels (Part 1 ) ............. F4-4

4-5. Flush $G$ and $R$ Cell Vessels (Part 2) ............. F4-5

4-6. Flush Backcycle Waste and Neptunium Package Vessels ..... F4-6

4-7. Flush U Cell Vessels .................. F4-7

4-8. Flush Cladding Waste Vessels . . . . . . . F4-8

4-9. Flush Tank D5, Tank E6, Tank F13, Tank F15, and

Tank Fl6 Vessels .................... F4-9

4-10. Flush Fll system Vessels . . . . . . . . . . . F4-10

4-11. Flush Tank G5A, Tank G7, and Tank G8 Vessels ....... F4-11

4-12. Flush Aqueous Makeup Tank $156 \ldots$. . . . . . . . . . . F4-12

TABLE

4-1. Vessel Systems Analytical Data ............. T4-1 
DOE/RL-95-78, Rev. 0

$06 / 96$

1
2
3
4
5

This page intentionally left blank. 


\subsection{MASTE CHARACTERISTICS}

This chapter describes the waste and associated activities with the vessel systems within the PUREX Facility. Discussion is limited to those permitted dangerous and/or mixed waste treatment and/or storage vessels.

\subsection{VESSEL SYSTEMS}

The vessel systems were each identified as part of 12 loops (Figures 4-1 through 4-12) designated for flushing. Flush solutions were cascaded within each vesse1. Samples were taken in a tank at the end of the flush loop. In addition to the 12 flush loops, tanks F4, M2, P4, and U3, individually were flushed and sampled. Tanks $40, Q 21$, and Q22 were not sampled because the tanks have bottom drains, which left no heel.

For each vessel within a flush loop, screening samples were taken of flushes unti] laboratory results indicated the waste no longer exhibited dangerous waste characteristics. After screen sampling was completed, sampling was conducted in accordance with RCRA protocol and the data quality objectives (DQOS) (WHC 1995c). The DQOS for this sampling effort define the sampling and analysis necessary to support the flushing of the vessel systems that are WAC 173-303 regulated.

Regulated dangerous waste constituents within the mixed waste varied by 10op. The primary dangerous waste constituents removed during transition phase activities were cadmium, chromium, and nitric acid. Radioactive components of the mixed waste are attributed to past processing activities. If the flush solution was designated as a dangerous waste, the system was reflushed and sampled until results indicated the flush solution no longer designated as dangerous waste. Sampling results are listed in Table 4-1.

\subsection{CONTAINMENT BUILDING}

Elemental lead used as weights, counterweights, and/or radiation shielding and elemental cadmium, used as radiation shielding, was stored on the canyon deck of the containment building. As part of the transition phase activities, the lead and cadmium waste was moved to storage in PUREX Storage Tunnel Number 2. Additionally, F Cell contains chromium, which is a corrosion product of stainless steel and nitric acid. The chromium is contained within concrete debris, collected from the floor of $E$ Cell. Interim storage in $F$ Cell was chosen as the best stabilization method for this material because interim storage was environmentally sound, considered personnel safety, and was cost effective. The waste in $F$ Cell will remain in place through the S\&M phase, and will be dispositioned during closure. 


\section{DOE/RL-95-78, Rev. 0}

06/96

This page intentionally left blank. 


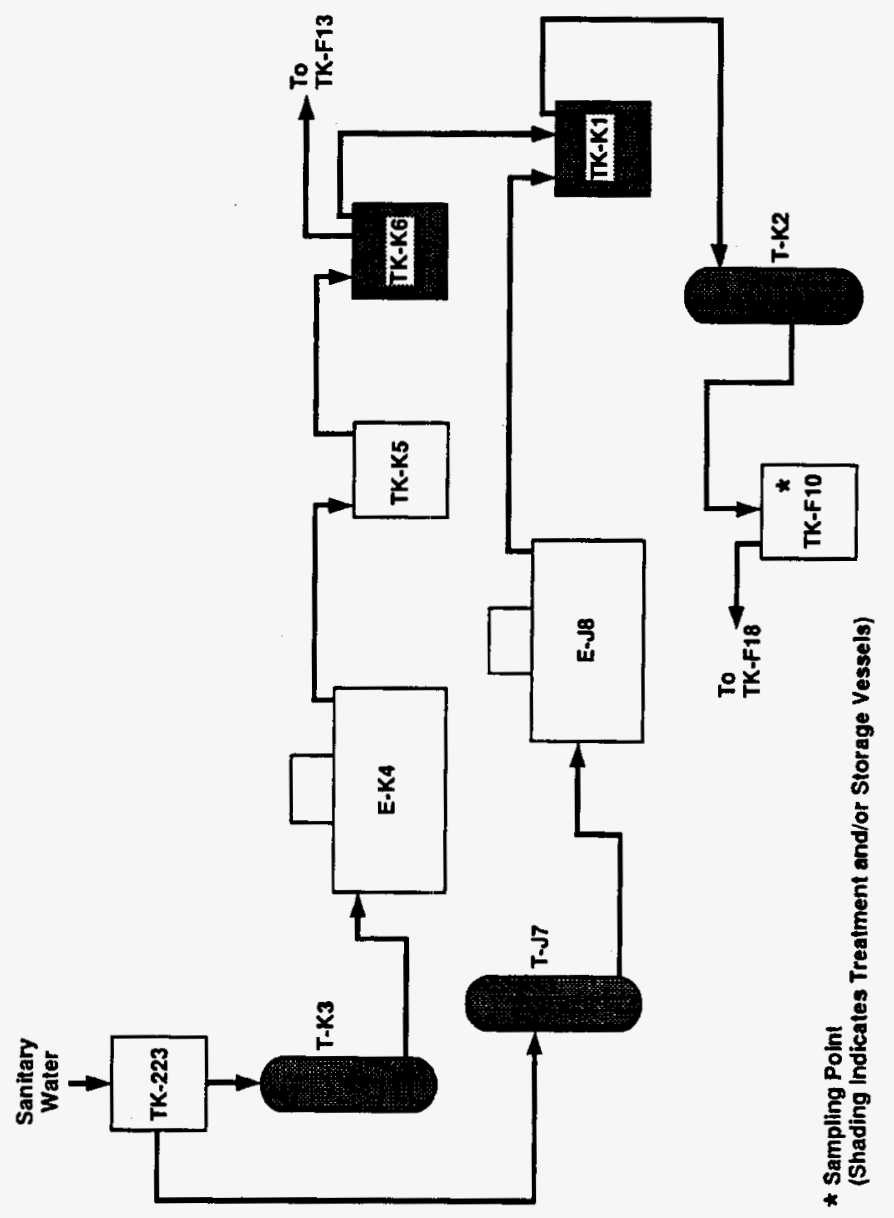

Figure 4-1. Flush K Cell Vessels. 
THIS PAGE INTENTIONALLY LEFT BLANK. 


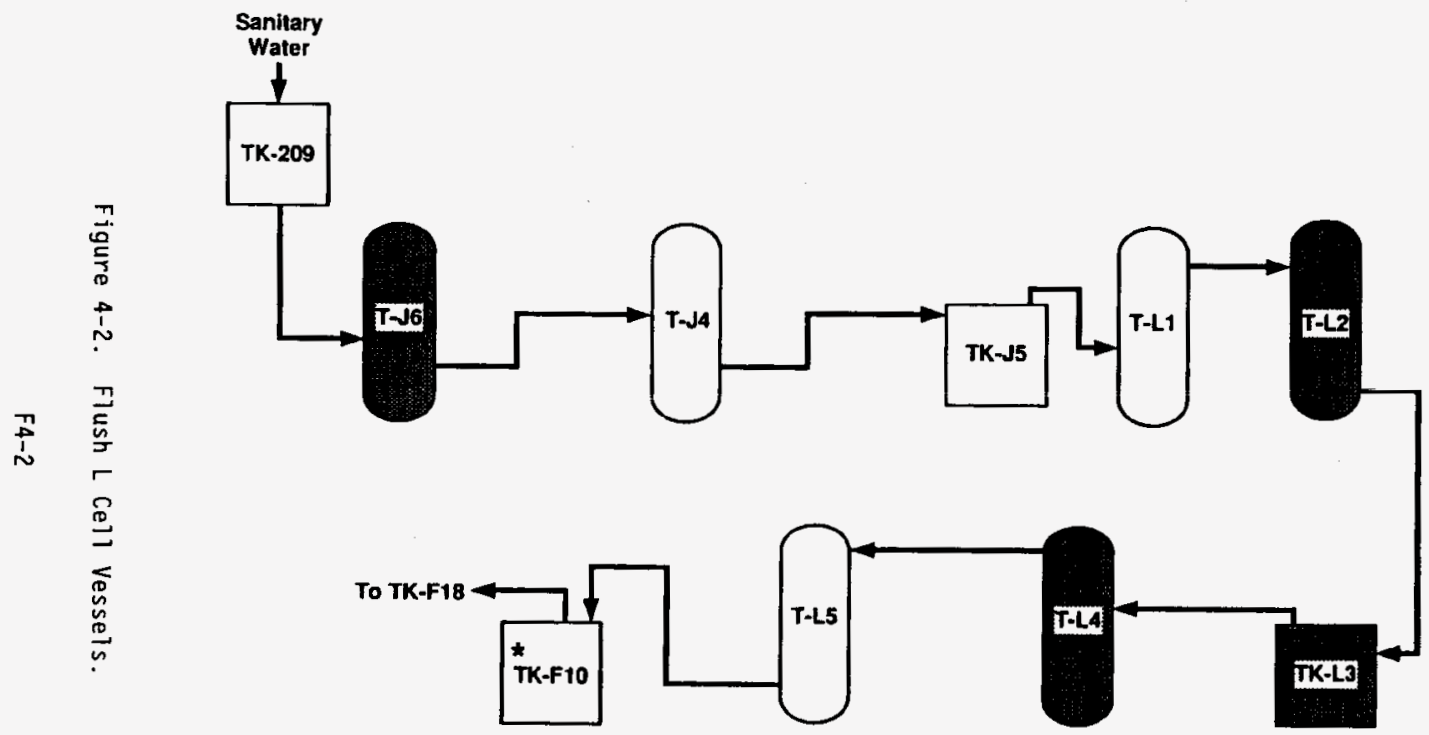

* Sampling Point

(Shading Indicates Treatment and/or Storage Vessels)

196030186.29 
THIS PLEE NTENTIONALLY LEFT BLANK. 


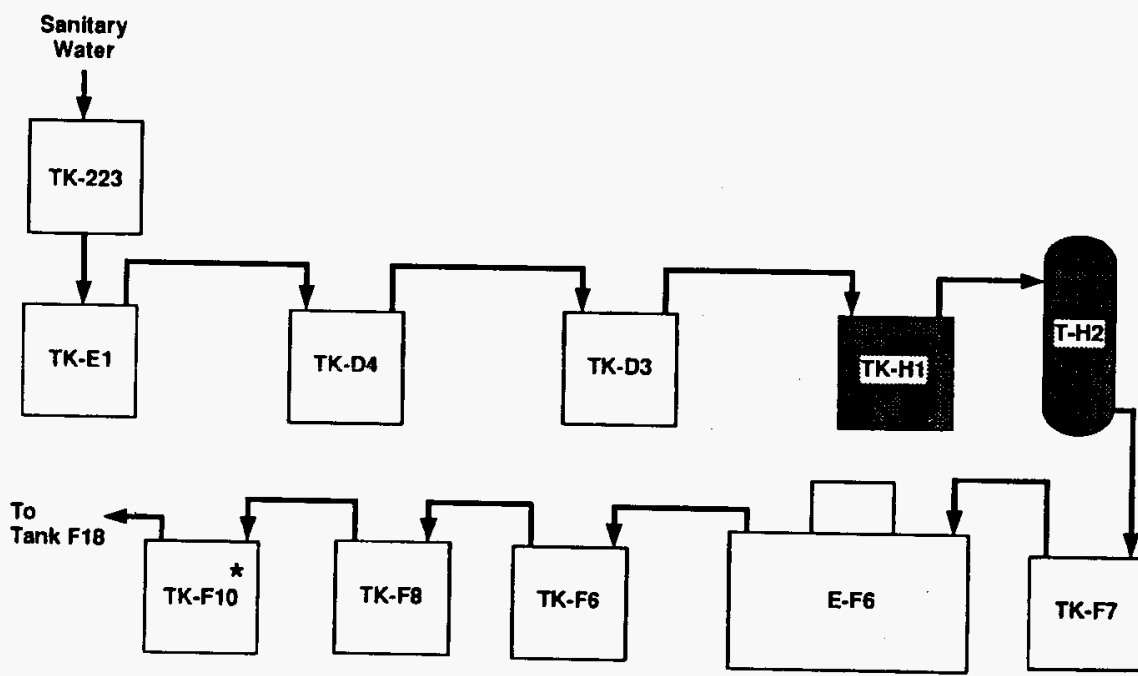

* Sampling Point

(Shading Indicates Treatment and/or Storage Vessels) 
THS PAGE INTENTIONALLY LEFT BLANK. 
D0E/RL-95-78, Rev. 0

$06 / 96$

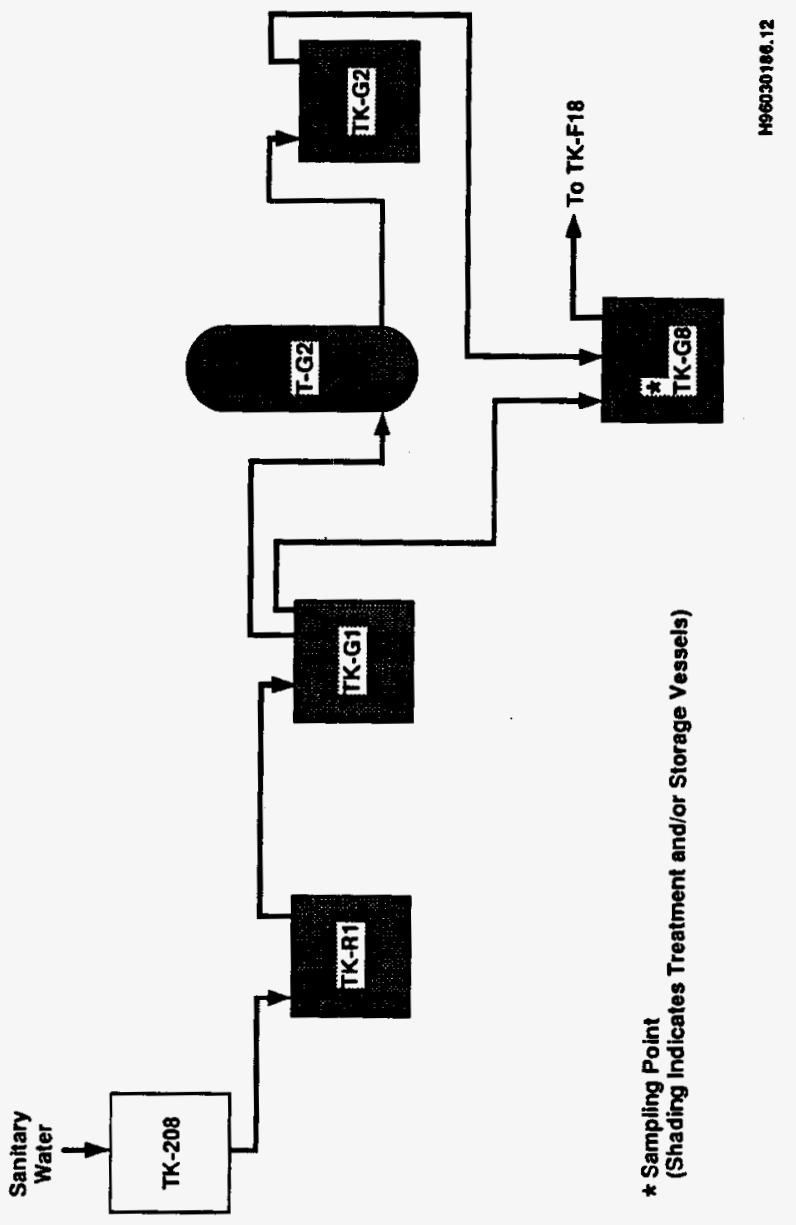

Figure 4-4. Flush $G$ and $R$ Cell Vessels (Part 1). 
THIS PAGE INTENTIONALLY LEFT BLANK. 


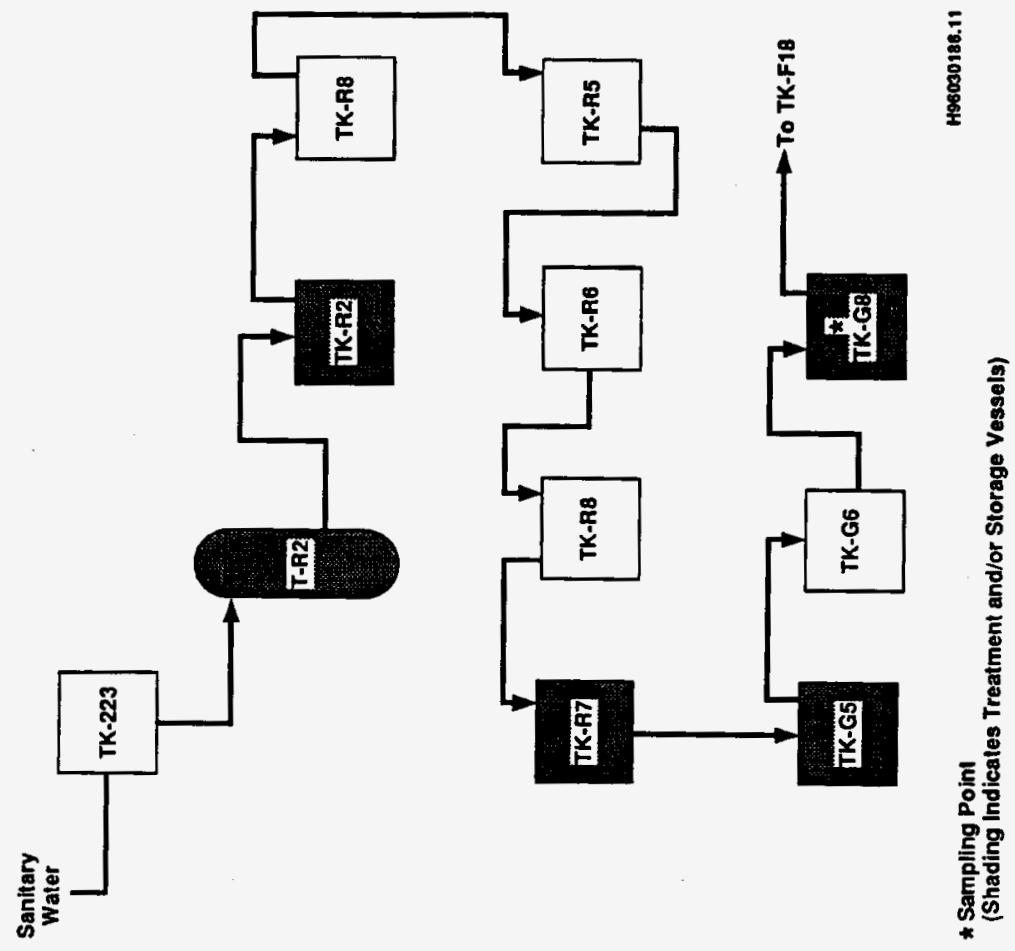

Figure 4-5. Flush $G$ and $R$ Cell Vessels (Part 2). 
THS PAGE INTENTIONALLY LEFT BLANK. 


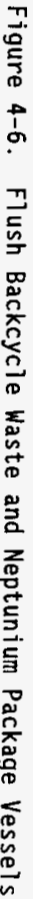

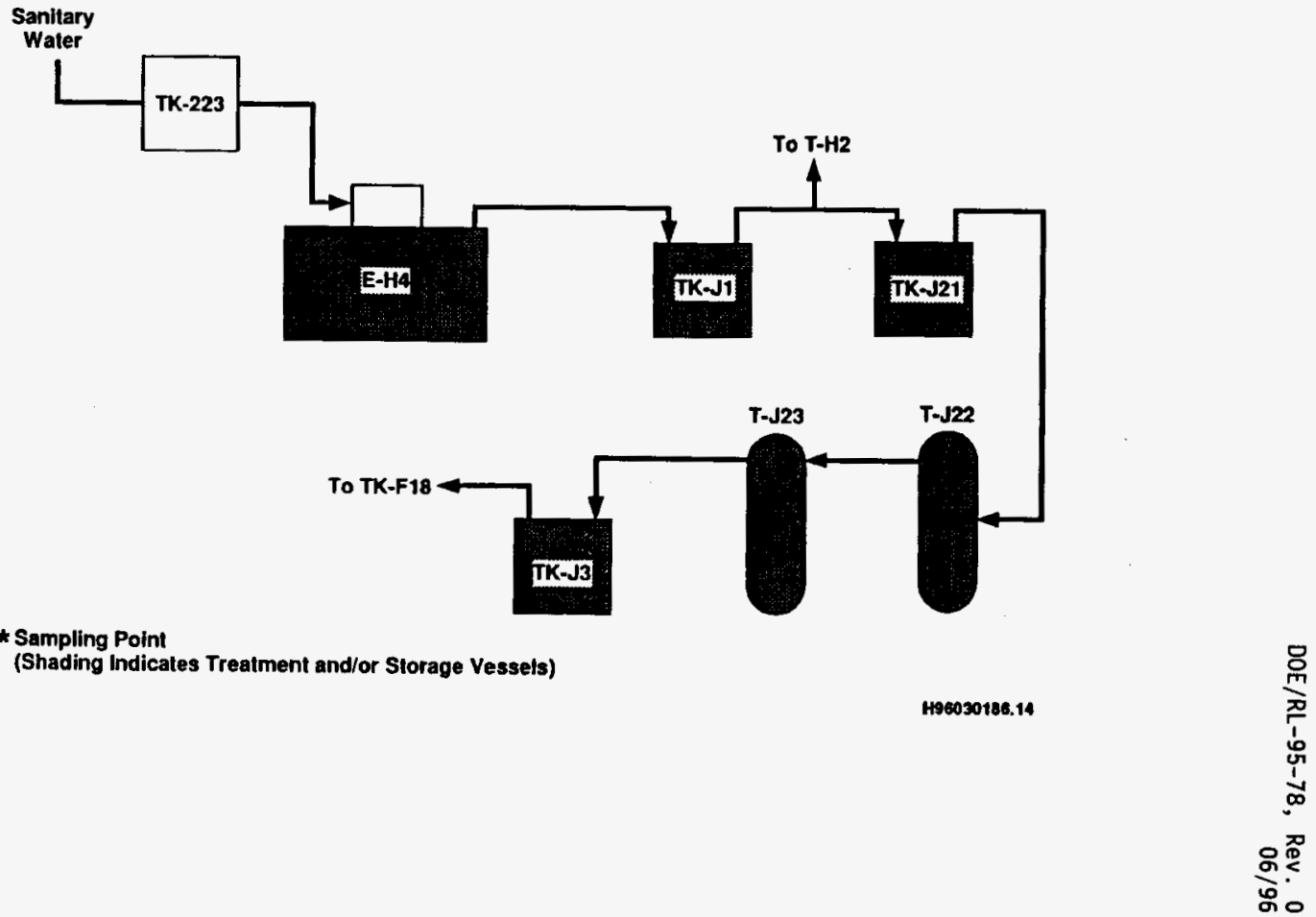


THS PAGE INTENTIONALLY

LEFT BLANK. 


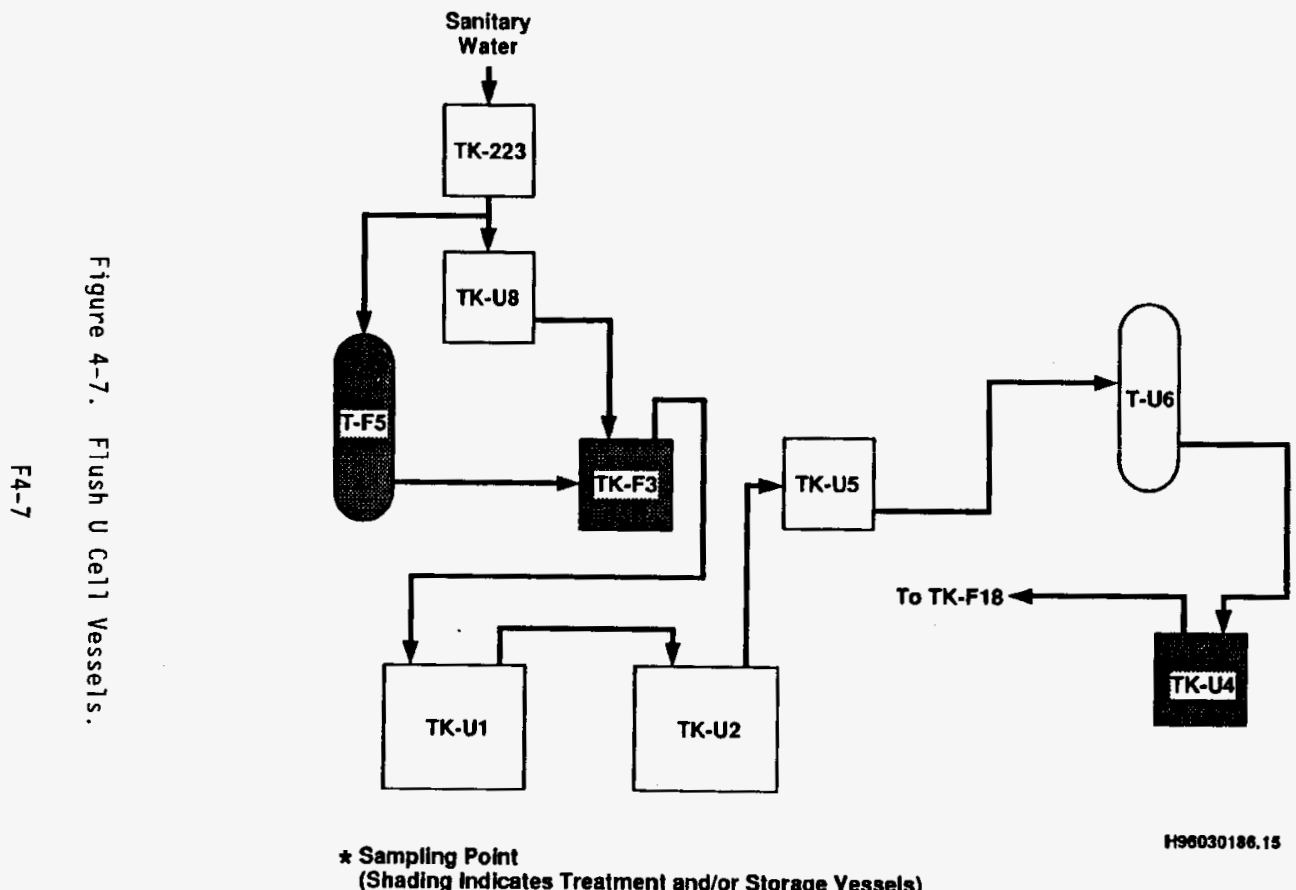

(Shading Indicates Treatment and/or Storage Vessels) 
THIS PAGE INTENTIONALLY

LEFT BLANK. 


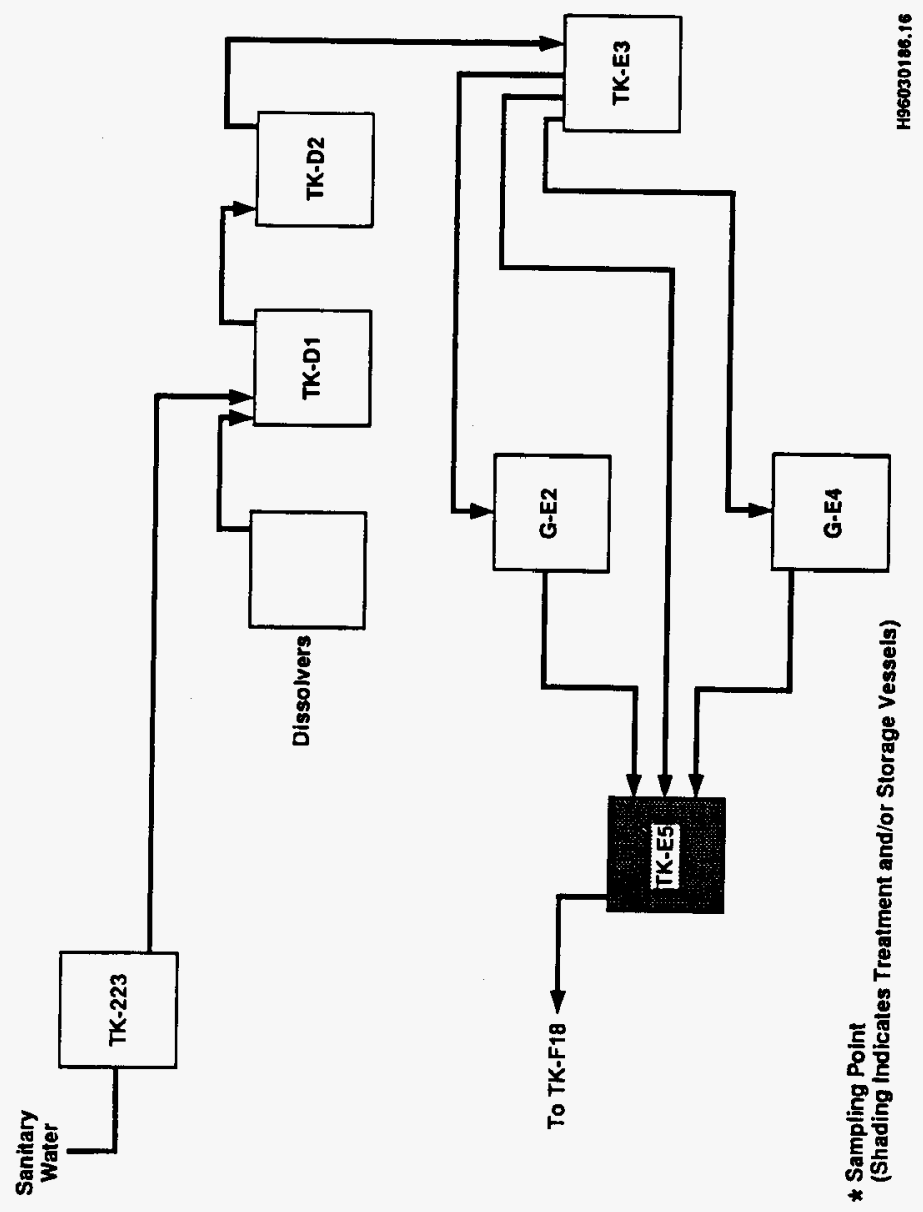

Figure 4-8. Flush Cladding Waste Vessels. 
THS PAGE INTENTIONALLY LEFT BLANK 
DOE/RL-95-78, Rev. 0

06/96

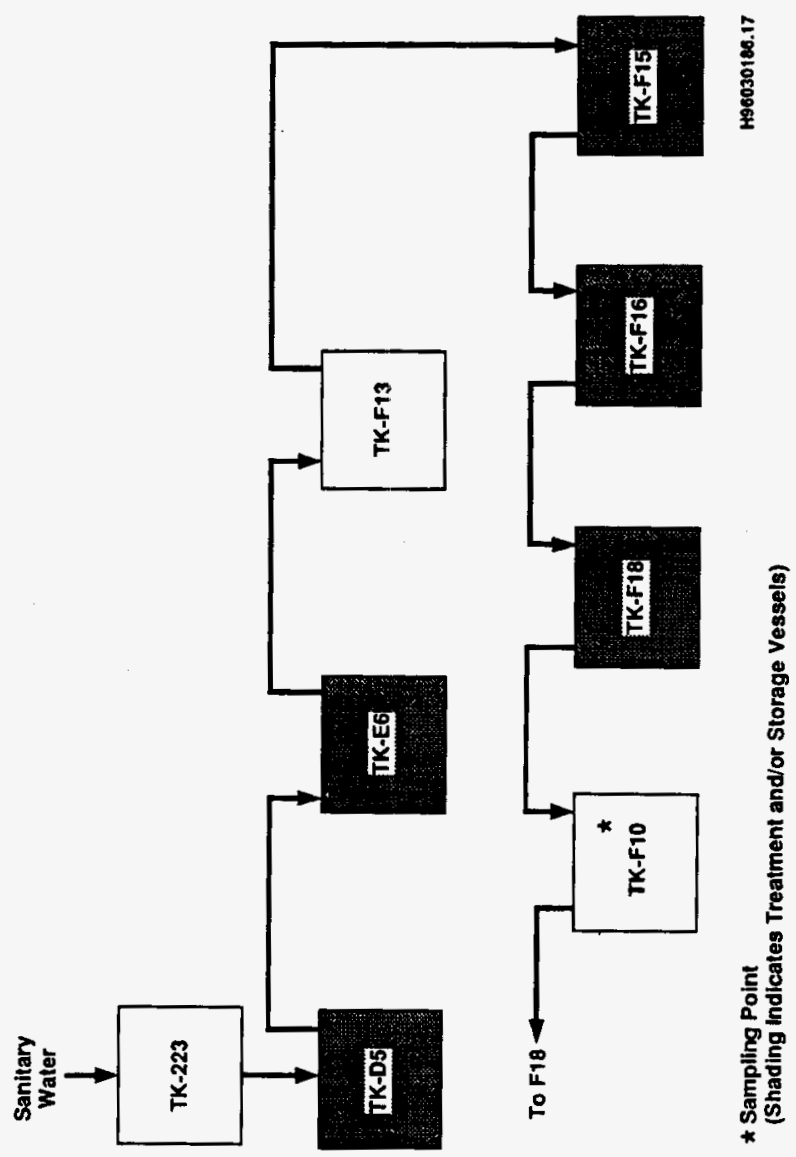

Figure 4-9. Flush Tank D5, Tank E6, Tank F13, Tank F15, and Tank F16 Vessels. 
THIS PAGE INTENTIONALLY LEFT BLANK. 


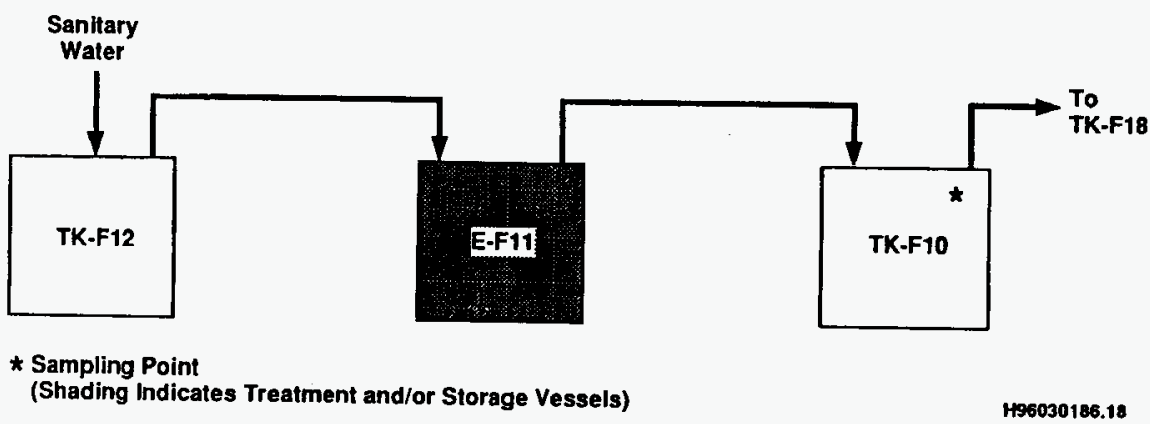

$$
\begin{aligned}
& \text { 号 } \\
& \text { 용 } \\
& \text { ถั. }
\end{aligned}
$$


THIS PACE INTENTIONALLY

IETT BLANK. 
DOE/RL-95-78, Rev. 0

06/96

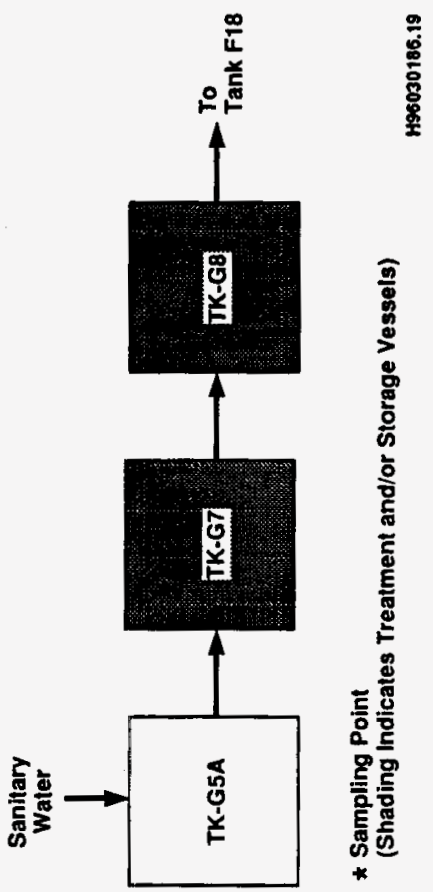

Figure 4-11. Flush Tank 65A, Tank 67, and Tank G8 Vessels. 
THS PAGE INTENTIONALLY

LEFT BLANK. 


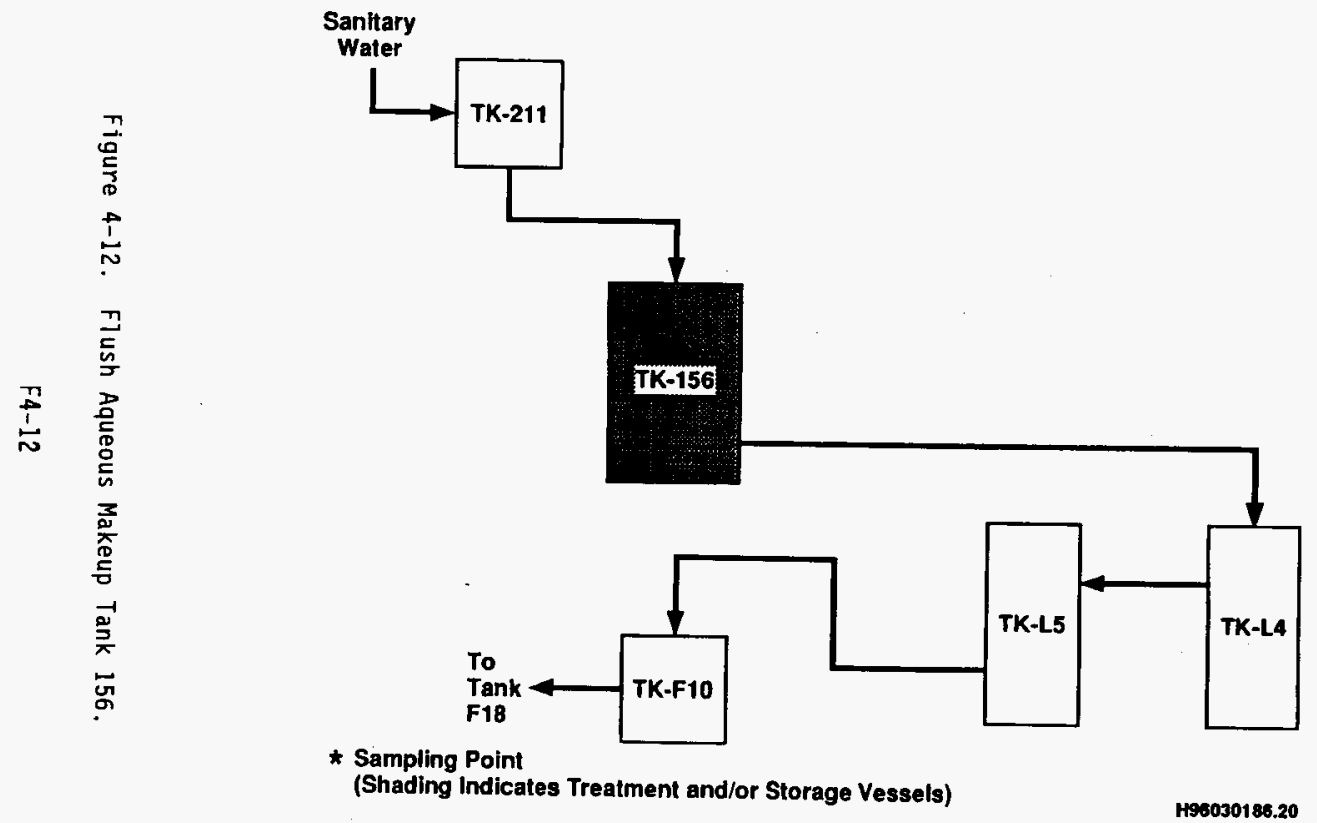


THE PAGE INTENTIONALLY LEFT BLANK. 
Table 4-1. Vessel Systems Analytical Data. (sheet 1 of 4)

\begin{tabular}{|c|c|c|c|c|c|c|c|c|c|c|c|}
\hline Vessols' & Samplo no. & $\begin{array}{l}\text { Cadmium } \\
(\mathbf{m g} / \mathrm{L})\end{array}$ & $\begin{array}{l}\text { Chromium } \\
\text { (mg/L) }\end{array}$ & $\begin{array}{l}\text { Lead } \\
\{m g / L]\end{array}$ & $\begin{array}{l}\text { Barium } \\
\text { (mg/L) }\end{array}$ & $\begin{array}{l}\text { Stiver } \\
\text { (mg/L) }\end{array}$ & $\begin{array}{l}\text { Arabnic } \\
(\mathrm{mg} / \mathrm{L})\end{array}$ & $\begin{array}{l}\text { Solenium } \\
\text { (mg/L) }\end{array}$ & $\begin{array}{l}\text { Mercury } \\
(\mathrm{mg} / \mathrm{l})\end{array}$ & $\begin{array}{c}\mathrm{pH} \\
(\mathrm{mg} / \mathrm{l})\end{array}$ & $\begin{array}{c}\text { TOC } \\
(m g / L)\end{array}$ \\
\hline $\begin{array}{l}\text { Dangerous waste designation } \\
\text { throshald }\end{array}$ & & 1.0 & 5.0 & 5.0 & 100.0 & 5.0 & 5.0 & 1.0 & 0.2 & $2<\mathrm{pH}<12.5$ & 100,000 \\
\hline $\begin{array}{l}\text { K-Cell Vessols (Completo) } \\
\text { (T-J7,E-J8, IK-K1,T-K2,T-K3 } \\
\text { E-K4,TK-K5, TK-K6) }\end{array}$ & 'R6331 & 0.06 & 0.336 & $<0.6$ & 0.342 & $<0.06$ & $<0.005$ & $<0.005$ & $<0.005$ & 2.73 & 203 \\
\hline $\begin{array}{l}\text { L-Coll Vessels (Complote) } \\
\text { (T-J6, T-J4,TK-J5,T-L1,T-L2, } \\
\text { TK-L3,T-L4,T-L5,TK-F10) }\end{array}$ & $\begin{array}{l}\text { "BOOVL1 } \\
\text { "BOFBT5 }\end{array}$ & 0.165 & 0.784 & 0.027 & 0.358 & 0.004 & 0.001 & 0.001 & 0.015 & $\begin{array}{l}1.47 \\
2.39^{2}\end{array}$ & 258 \\
\hline $\begin{array}{l}\text { Headend Foed Vessels,H1,H2, } \\
\text { and F-Cell Vessels (Complete) } \\
\text { (TK-E1,TK-D4,TK-D3,IK-H1, } \\
\text { T-H2, TK-F7,E-F6,TK-F26, } \\
\text { TK-F8) }\end{array}$ & "BODVL7 & $<0.1$ & 1.4 & $<1.1$ & $<5.0$ & $<1.0$ & $<0.125$ & $<0.25$ & $<0.005$ & 2.57 & 91.8 \\
\hline $\begin{array}{l}\text { G and R Cell Vossels (P art It } \\
\text { (Complete) } \\
\text { (TK-R1,TK-G1,T-G2,TK-G2) }\end{array}$ & •R6636 & 0.678 & 1.06 & $<0.6$ & $<0.3$ & $<0.06$ & $<0.005$ & 0.0065 & $<0.005$ & 7.62 & 444 \\
\hline $\begin{array}{l}\text { G and R Cell Varsels (Part III } \\
\text { [Completel } \\
\text { (T-A2,TK-R2,TK-R8,TK-R5, } \\
\text { D-R6,IK-R7,TK-G5,D-G6] }\end{array}$ & -R6714 & $<0.11$ & 0.616 & $<1.1$ & $<0.55$ & $<0.11$ & $<0.25$ & $<0.25$ & $<0.25$ & 10.67 & 2100 \\
\hline $\begin{array}{l}\text { Backeyclo Waste and } \\
\text { Neptunium Packago Ves sels } \\
\text { (Completol } \\
\text { (E-H4,TK-J1,TK-J21,T-J22, } \\
\text { T-J23, IK-J3) }\end{array}$ & •R6990 & $<0.01$ & 0.867 & $<0.1$ & 0.291 & $<0.01$ & $<0.25$ & $<0.25$ & $<0.005$ & 2.89 & 171 \\
\hline $\begin{array}{l}\text { U-Cell Vossels (Complote) } \\
\text { (TK-UB,T-F5,TK-F3,TK-U1, } \\
\text { TK-U2,TK-U5,T-U6,TK-U4) }\end{array}$ & $\begin{array}{l}.95013- \\
01.806\end{array}$ & $0.34(U)$ & $0.73(B)$ & $3.4(U)$ & $0.39(B)$ & $0.5(U)$ & $0.1(U)$ & $0.1\{U\}$ & $0.05(U)$ & 2.94 & $0.025(U)$ \\
\hline $\begin{array}{l}\text { Cladding Waste Vossels } \\
\text { (Complete) } \\
\text { (TK-D1.TK-D2.TK-E3,G-E2, } \\
\text { G-E4.TK-E5) }\end{array}$ & “R6995 & $<0.6$ & 0.396 & $<0.6$ & $<0.3$ & $<0.06$ & $<0.25$ & $<0.25$ & $<0.005$ & 9.44 & 29.7 \\
\hline $\begin{array}{l}\frac{\text { TK-D5,TK-E6 }}{\text { and TK-F13,IK-F15, }} \\
\frac{\text { Vossels (Complote) }}{\text { Vols }}\end{array}$ & "BofBS9 & 0.074 & 0.215 & 0.041 & 0.121 & 0.002 & 0.001 & 0.001 & 0.009 & 2.33 & 144 \\
\hline $\begin{array}{l}\text { F11 System Vessels (Complete) } \\
\text { (TK-F12, E-F11) }\end{array}$ & 'BOFBT2 & 0.0038 & 0.0421 & 0.0413 & 0.021 & 0.002 & 0.001 & 0.001 & 0.0019 & 5.86 & 160 \\
\hline
\end{tabular}


THIS PAGE NTENTIONALLY LEFT BLANK. 
Table 4-1. Vessel Systems Analytical Data. (sheet 2 of 4)

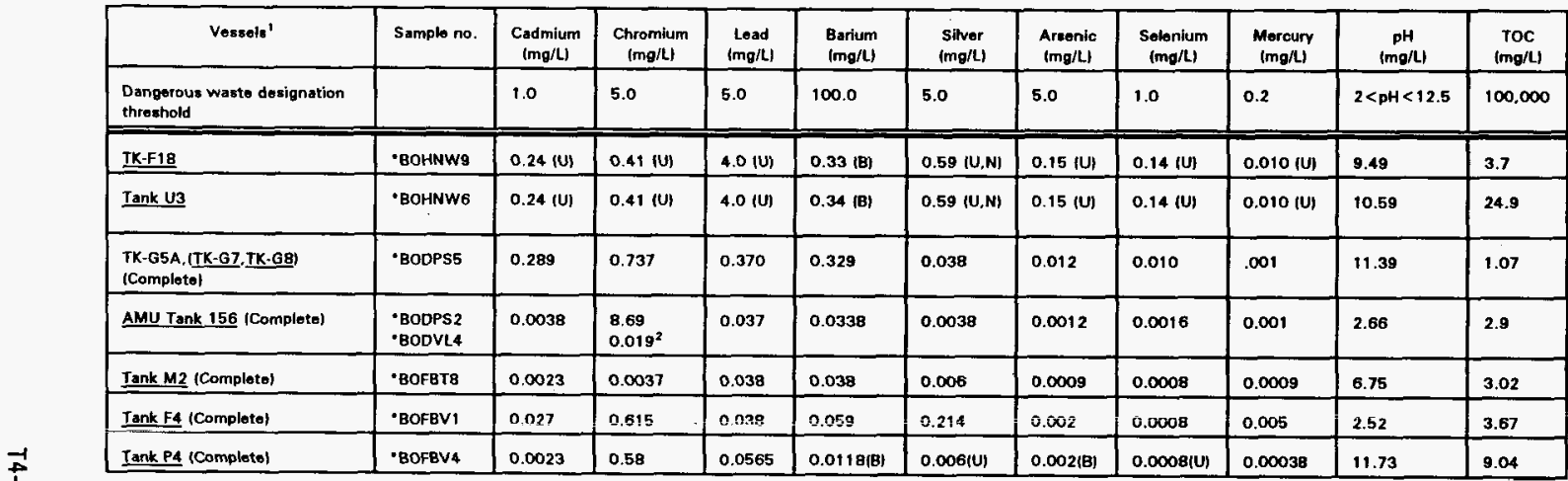


THIS PAGE INTENTONALLY

LEFT BLANK. 
Table 4-1. Vessel Systems Analytical Data. (sheet 3 of 4)

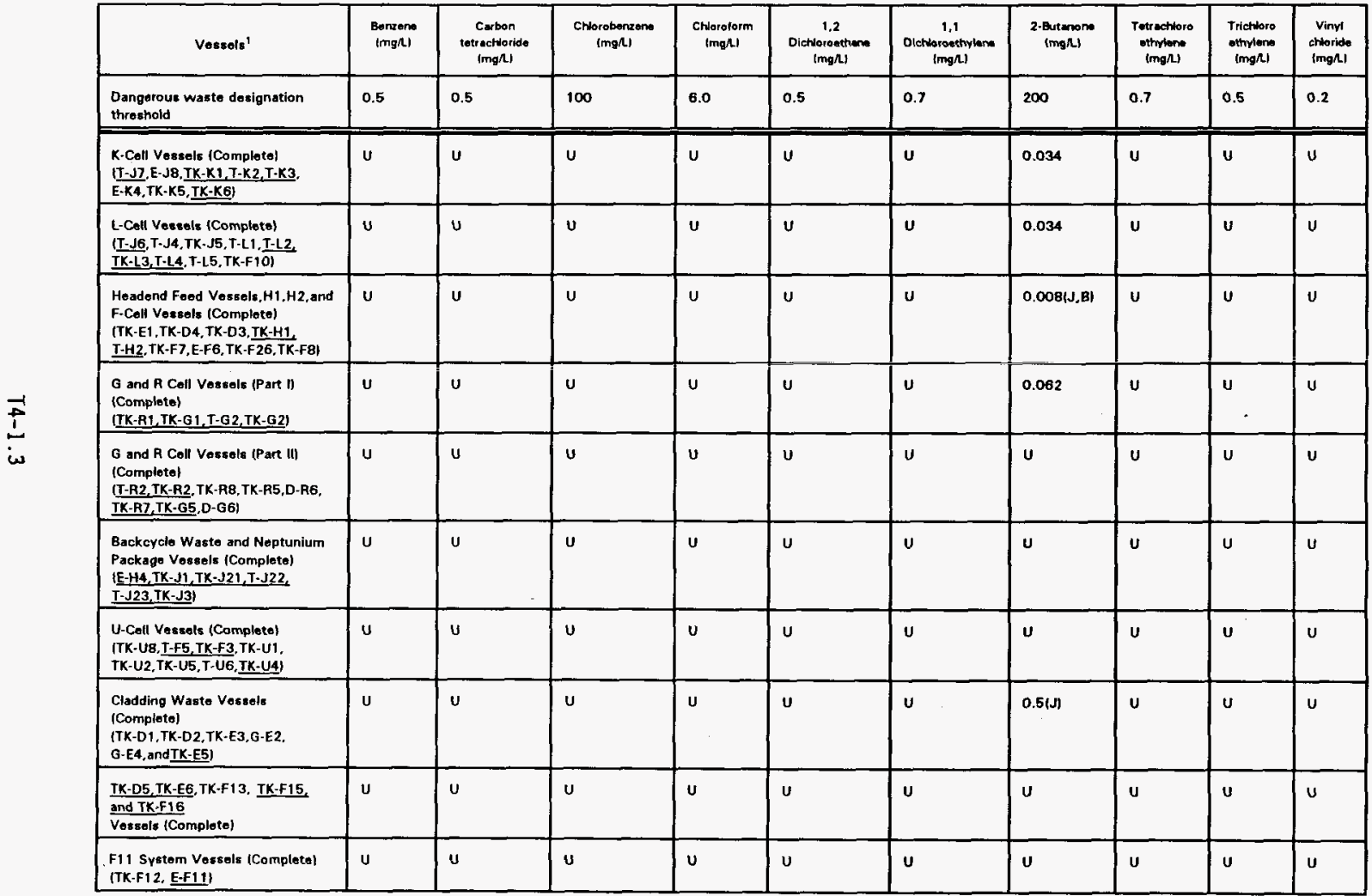


THIS PAGE INTENTIONALLY LEFT BLANK. 
Table 4-1. Vessel Systems Analytical Data. (sheet 4 of 4)

\begin{tabular}{|c|c|c|c|c|c|c|c|c|c|c|}
\hline Vessels' & $\begin{array}{l}\text { Berzane } \\
\text { (mgh) }\end{array}$ & $\begin{array}{l}\text { Curben } \\
\text { tetroctioride } \\
\text { (mg/L) }\end{array}$ & $\begin{array}{l}\text { Chlorobantem } \\
\text { (mgn) }\end{array}$ & $\begin{array}{l}\text { Ctuarotarm } \\
\text { (mgh) }\end{array}$ & $\begin{array}{l}9.2 \\
\text { Dictiorouthene } \\
\text { (mingh) }\end{array}$ & $\begin{array}{c}1,1 \\
\text { Dichloroethylense } \\
\text { (migh) }\end{array}$ & $\begin{array}{l}\text { 2-Butmone } \\
\text { (mgh) }\end{array}$ & $\begin{array}{c}\text { Totrachioro } \\
\text { othylene } \\
\text { (mingh) }\end{array}$ & $\begin{array}{l}\text { Trichloro } \\
\text { othylone } \\
\text { (migh) }\end{array}$ & $\begin{array}{l}\text { Vinyl } \\
\text { enloride } \\
\text { (ming) }\end{array}$ \\
\hline $\begin{array}{l}\text { Dangerous waste designation } \\
\text { threshold }\end{array}$ & 0.5 & 0.5 & 100 & 6.0 & 0.5 & 0.7 & 200 & 0.7 & 0.5 & 0.2 \\
\hline IK-F18 & $\mathbf{u}$ & u & $u$ & $u$ & u & $\mathbf{u}$ & $u$ & $\mathbf{u}$ & u & $\mathbf{u}$ \\
\hline Tank U3 & $\mathbf{u}$ & u & $\mathbf{u}$ & $u$ & $\mathbf{u}$ & $u$ & $\mathbf{u}$ & $\mathbf{u}$ & u & $u$ \\
\hline $\begin{array}{l}\text { TK-G5A.(TK-GZ,TK-G8) } \\
\text { (Complete) }\end{array}$ & $\mathbf{u}$ & $\mathbf{u}$ & $u$ & $\mathbf{u}$ & $\mathbf{u}$ & $\mathbf{u}$ & $\mathbf{u}$ & $\mathbf{u}$ & $0.012(J)$ & $\mathbf{u}$ \\
\hline AMU Tank 156 (Comploto) & $u$ & $\mathbf{u}$ & $u$ & 0.006 & $\mathbf{u}$ & $\mathbf{u}$ & $\mathbf{u}$ & $u$ & $\mathbf{u}$ & $\mathbf{U}$ \\
\hline Tank M2 (Comploto) & $\mathbf{u}$ & $\mathbf{u}$ & $\mathbf{u}$ & u & $\mathbf{u}$ & $\mathbf{u}$ & u & $u$ & $u$ & $\mathbf{u}$ \\
\hline Tank F4 (Comploto) & $u$ & $\mathbf{u}$ & $\mathbf{u}$ & u & $\mathbf{u}$ & $\mathbf{u}$ & $\mathbf{u}$ & $u$ & $\mathbf{u}$ & $\mathbf{u}$ \\
\hline Tank P4 (Complote) & $u$ & $\mathbf{U}$ & $u$ & $\mathbf{u}$ & $\mathbf{u}$ & $\mathbf{u}$ & $\mathbf{u}$ & $\mathbf{u}$ & $\mathbf{u}$ & $u$ \\
\hline
\end{tabular}

- Sample analyzed by Quanterra Laboratory.

- Sample analyzed by 222 -s Laboratory.

' Underlining indicatos permittod vessels (DOE/RL-88-21).

2 Analytical results after reflushing and resampling.

$\mathrm{mg} / \mathrm{L}=$ milligrams per liter.

$\mathrm{TOC}=$ total organic carbon.

$\mathrm{U}=$ analyzed but not detectod.

$=$ interference dotected in matrix.

= compound was found in the blank.

= an ostimated value for the target or tentativoly ldentified compound. 
IMO HAGE INTENTIONALLY

LEFT BLANK. 


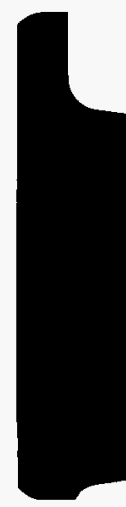




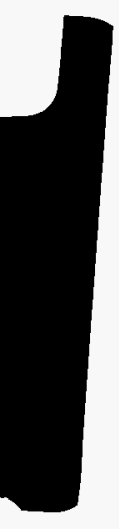


D0E/RL-95-78, Rev. 0

06/96

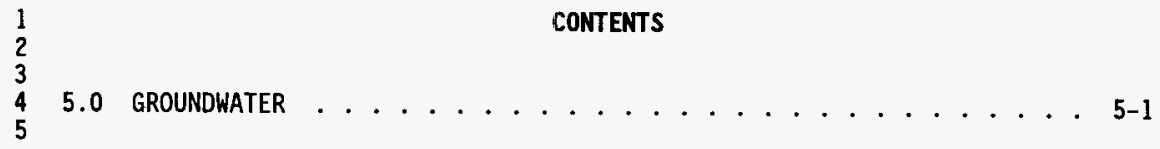


DOE/RL-95-78, Rev. 0

This page intentionally left blank. 


\subsection{GROUNDWATER}

In accordance with the Tri-Party Agreement, groundwater in the 200 East Area will be included in the 200-P0-1 operable unit and will be investigated under Comprehensive Environmental Response, Compensation, and Liability Act (CERCLA) of 1980. Therefore, groundwater investigation/remediation is not addressed as part of this preclosure work plan. Work on the 200-P0-1 operable 9 unit will be coordinated with the final disposition process but will not occur 10 until the final groundwater operable unit work plan has been approved. 
DOE/RL-95-78, Rev. 0

$06 / 96$

1
2
3
4
5

This page intentionally left blank. 
㗀

褰

$\frac{5}{\frac{5}{6}}$

焉

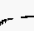

0

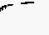

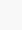

(n)

.
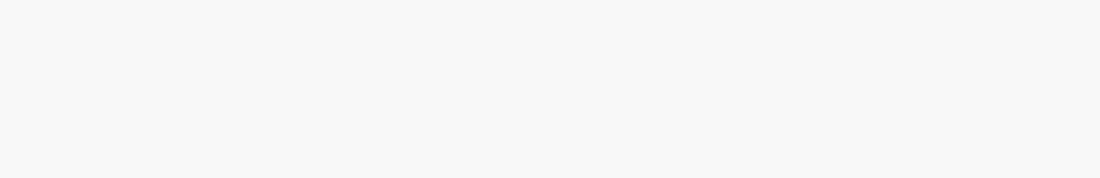
DOE/RL-95-78, Rev. 0

$06 / 95$

1

\section{CONTENTS}

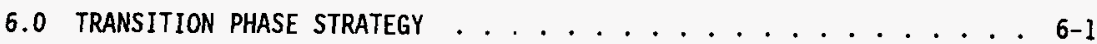

6.1 SURVEILlance AND MAINTENANCE ............... . . . . . .

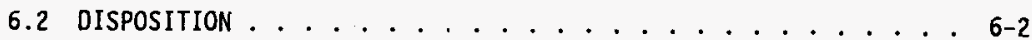


DOE/RL-95-78, Rev. 0

06/96

This page intentionally left blank. 


\subsection{TRANSITION PHASE STRATEGY}

This chapter describes the transition phase strategy and provides a general description of the S\&M phase and disposition phase activities.

Preclosure of the PUREX Facility vessel systems will occur in conjunction with the overall decommissioning of the PUREX Facility. The transition phase activities places the PUREX Facility in a deactivated state where all vessels are flushed until the solutions do not designate as dangerous waste. Any hazardous substances (e.g., lead shielding, etc.) left in place will be identified during the transition phase and managed during the disposition phase. The S\&M phase will maintain the PUREX Facility in a safe and environmentally secure configuration for 10 or more years for a planning horizon. The disposition phase will address final closure activities [for portions of the PUREX Facility identified in the Part A, Form 3, Permit Application (DOE/RL-88-21)] in accordance with WAC 173-303. If required, postclosure care requirements would be integrated with the post-remediation groundwater monitoring requirements established for the 200-P0-1 operable unit.

This phased approach to closure allows for an expedient full deactivation of the PUREX Facility in a manner that is safe and cost-effective, while minimizing the risk to human health and the environment.

The transition phase activities will place the PUREX Facility in a deactivated state. The transition phase consists of completion of end point criteria (WHC 1995b), flushing vessel systems until threshold levels are met, and transfer of the lead and cadmium waste from the canyon deck to PUREX Storage Tunnel Number 2.

End point criteria are used to achieve a safe, stable, and environmentally secure facility suitable for a low cost S\&M program. End points were created to ensure a thorough measure of completeness in preparing the PUREX Facility for future decontamination and decommissioning. End point criteria currently are being used to confirm completion of transition phase activities and to substantiate the readiness for transition to the S\&M phase (Ecology et al. 1996; WHC 1995b).

\subsection{SURVEILLANCE AND MAINTENANCE}

During the S\&M phase, the PUREX Facility will be unoccupied and locked. There will be no active systems or utilities (except the electrical, lighting, and heating, ventilation, and air conditioning systems) within the building. The existing filtered exhaust systems that maintain a negative pressure within the PUREX Plant will be consolidated into a single system monitored from a remote location. The S\&M plan (WHC 1995b) addresses compliance with RCRA and WAC 173-303 requirements. The S\&M plan outlines activities taken to address monitoring of essential systems and to maintain the area in a safe condition that presents no significant threat of release of hazardous substances into the environment and no significant risk to human health and the environment 
1 until final disposition is completed. The completion of these activities are 2 necessary before the final disposition of the PUREX Facility can be

3 implemented.

4

5

\section{$6 \quad 6.2$ DISPOSITION}

All aspects of closure not covered during the transition or S\&M phases

9 will occur during the disposition phase (i.e., end state of the systems,

10 hazardous substances left in place, end state of the canyon structure, and

11 integration with the CERCLA remedial activities). 


$$
1
$$




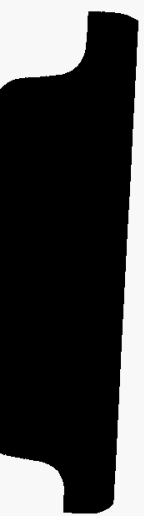


DOE/RL-95-78, Rev. 0

$06 / 96$

\section{CONTENTS}

7.0 transition PHASE ACtIVITIES ............... . . . . . . .

7.1 REMOVAL OF DANGEROUS WASTE RESIDUE AND CONTAMINATED

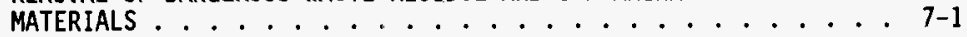

7.2 SAMPLING AND ANALYSIS .............. . . . . .

11 
DOE/RL-95-78, Rev. 0

06/96

This page intentionally left blank. 


\subsection{REMOVAL OF DANGEROUS WASTE RESIDUE AND CONTAMINATED MATERIALS}

Preclosure of the vessel systems includes the following activities:

- Removing residual solutions

- Flushing vessel systems until the heels do not exhibit dangerous waste characteristics

- Conducting protocol sampling and analysis of final (record) flushes of vessel systems as defined in Section 7.2.1

- Emptying vessels to the maximum extent practicable using existing pumps and/or jets

- Emptying cell sumps to the normal heel using existing jets and/or pumps

- Isolating (blanking) all liquid feed and/or drain lines to vessel systems.

Following the completion of all vessel system flushing, the liquid level in the vessels will be left at the lowest level possible (the residual heels vary between approximately 70 and 400 liters) using existing jets and/or pumps. All liquid feed and/or drain lines will be isolated after emptying the vessel systems and cell sumps to prevent any inadvertent backflow of liquids.

The following transition phase activities minimizes the required S\&M of the containment building and will aid in the protection of human health and the environment during the S\&M phase.

All bare lead and cadmium on the canyon deck has been transferred to PUREX Storage Tunnel 2 for long-term storage. 
1 Some dangerous and/or mixed waste ( $F$ Cell) will remain in storage in the 2 containment building. Surveillance of the containment building is discussed 3 in Chapter 3.0 , Section 3.4 .

When transition activities are completed, the personnel entries will be locked and appropriate warning signs (e.g., "Danger - Unauthorized Personnel Keep Out" and "Radiation Zone") will be posted.

\subsection{SAMPLING AND ANALYSIS}

The vessel systems will be flushed until the heels do not exhibit dangerous waste characteristics (WHC 1995d). Flushing of the vessel systems ultimately will lead to closure of the vessel systems that are regulated by WAC 173-303.

The DQO planning process was used to develop the sampling and analysis approach used during transition activities (WHC 1995c).

Soil sampling and analysis will occur as part of the corrective action 21 investigation process of the 200-P0-2 operable unit. 


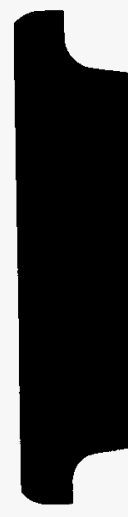




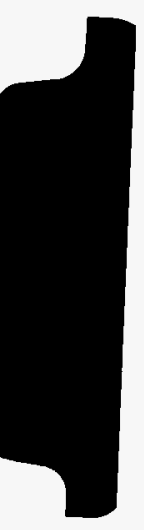


DOE/RL-95-78, Rev. 0

1

2

3

4 8.0 POSTClOSURE PLAN . . . . . . . . . . . . . . . 8-1 
D0E/RL-95-78, Rev. 0

$06 / 96$

This page intentionally left blank. 


$$
\text { DOE/RL-95-78, Rev. } 0
$$

\section{B.0 POSTCLOSURE PLAN}

If waste is left in place, a postclosure plan will address disposition scenarios. Groundwater contamination will be investigated and remediated through the operable units under the CERCLA remedial investigation/feasibility study process as specified in the Tri-Party Agreement. 
DOE/RL-95-78, Rev. 0

$06 / 96$

1
2
3
4
5

This page intentionally left blank. 



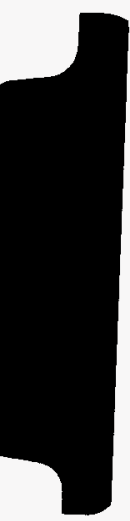


DOE/RL-95-78, Rev. 0

$06 / 96$

1

CONTENTS

3

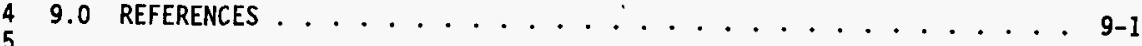


DOE/RL-95-78, Rev. 0

$06 / 96$

This page intentionally left blank. 


\subsection{REFERENCES}

DOE/RL-88-21, Hanford Facility Dangerous Waste Part A Permit Application, U.S. Department of Energy, Richland Operations Office, Richland, Washington.

DOE/RL-90-24, Hanford Facility Dangerous Waste Permit Application, PUREX Storage Tunnels, latest revision, U.S. Department of Energy, Richland Operations Office, Richland, Washington.

DOE/RL-90-39, Hanford Facility Dangerous Waste Permit Application, Double-Shell Tank System, latest revision, U.S. Department of Energy, Richland Operations Office, Richland, Washington.

D0E/RL-91-28, Hanford Facility Dangerous Waste Permit Application, General Information Portion, latest revision, U.S. Department of Energy, Richland Operations office, Richland, Washington.

Ecology, EPA, and DOE, 1996, Hanford Federal Facility Agreement and Consent Order (Tri-Party Agreement), Section 8.0, Washington State Department of Ecology, U.S. Environmental Protection Agency, U.S. Department of Energy, 01 ympia, Washington.

Giller, R.A, 1992, "Certification of the 202-A Building as a Dangerous Waste Containment Building", Internal Memo 92-RAG-043, Westinghouse Hanford Company, Richland, Washington.

ICBO 1952, Uniform Building Code, International Conference of Building officials, Whittier, California.

WHC, 1995a, PUREX Facility End Point Criteria, WHC-SD-WM-TPP-053, Westinghouse Hanford Company, Richland, Washington.

WHC, 1995b, PUREX Facility Surveil7ance and Maintenance P7an, (transmittal letter 9651858), Westinghouse Hanford Company, Richland, Washington.

WHC, 1995c, Sampling and Analysis Plan (SAP) for Plutonium-Uranium Extraction (PUREX) Plant Canyon Vessel Flushing, WHC-SD-CP-PLN-027 (this plan was used for sampling and analysis of all PUREX Facility vessels), Westinghouse Hanford Company, Richland, Washington. 
DOE/RL-95-78, Rev. 0 $06 / 96$

This page intentionally left blank. 


\section{DISTRIBUTION}

OFFSITE

MSIN

Washington State Department of Ecology

R. J. Julian, Kennewick Office

B5-18

J. Witczak

P.0. Box 47600

OIympia, WA 98504-7600

Confederated Tribes of the Umatilla Indian Reservation

J. R. Wilkinson

P.0. Box 638

Pendleton, OR 98701

Nez Perce Tribe

D. Powaukee

P.0. Box 305

Lapwaj, ID 80540

Confederated Tribes and Bands

of the Yakama Nation

D. Dogs 1eep

G1-02

R. Jim

P.0. Box 151

Toppenish, WA 98948

ONSITE

U.S. Department of Energy, Richland Operations office

G. M. Bell

A5-52

R. X. Gonzalez

R3-79

E. M. Mattlin

Public Reading Room (2)

A5- 15

H2-53

MAC Technical Services Company

M. Ciminera

B1-42

Pacific Northwest Laboratory

Hanford Technical Library

K1-11 


\section{DISTRIBUTION (cont)}

ONSITE

MSIN

Westinghouse Hanford Company

R. C. Bowman

H6-24

C. R. Haas

56-21

D. G. Hamrick

S6-15

D. G. Harlow

$56-19$

J. P. Hayfield

S6-19

W. G. Jasen

S6-19

S. E. Killoy

S4-66

D. M. Korematsu-0lund

H6-24

G. J. LeBaron

S6-19

M. R. Morton

$\times 5-53$

S. M. Price

H6-23

C. P. Strand

H6-24

C. N. Villalobos

S6-19

B. A. Ward

HO- 12

B. D. Williamson

B3-15

C. D. Woll am

L. C. Zins1i

S6-22

Central Files

S6-19

DPC

EDMC (2)

A3-88

A3-94

RCRA File (MWC)

H6- 08

H6-24 